\title{
LA VENTA DE SEÑORÍOS ECLESIÁSTICOS DE CASTILLA Y LEÓN EN EL SIGLO XVI
}

por

\section{M. á ÁGELES FAYA dÍAZ}

Universidad de Oviedo.

RESUMEN: Carlos V y Felipe II venderán señorios de la Iglesia a lo largo del siglo XVI; será uno de los expedientes utilizados ante las dificuliades financieras ocasionadas por su ambiciosa politica exterior. El trabajo proporciona una evaluación cuantitativa de los señorios eclesiasticos castellano-leoneses 1650 lugares con unos 41.000 vasallos), asi como un análisis del régimen señorial en esta zona geográfica. Podemos deducir de nuestra documentación la efectividad del poder señorial, del que los vasallos desean liberarse. Muchos pueblos de señorio aprovecharán esta coyuntura propicia para comprar al rey la jurisdicción. Por otro lado, las instituciones eclesiásticas argumentarán ante la Corona el perjuicio que les traeria estas ventas. La oposición de la Iglesia explica que las ventas afectaran solamente al $40 \%$ de los vasallos eclesiásticos de Castilla-León y que no se agotasen las cantidades permitidas por las bulas papales, base legal de las enajenaciones. La venta de jurisdicciones será muy rentable para la Corona; la Iglesia, por el contrario, resultará dañada al igual que los pueblos redimidos, mucbos de los cuales se endeudarán y tendrán que venderse a un señor.

PALABRAS CLAVE: España. Siglo XVI. Régimen señorial. Conflictos. Iglesia y Corona.

ABSTRACT: Charles $V$ and Pbilip II were to sell the manors of the Church throughout the 16 th century. This was to be one of the means used to combat the financial difficulties caused by their ambitious foreign policy. The work allows us a quantitative evaluation of the ecclesiastical manors in Castille and Leon (650 locations with approximately 41,000 vassals) as well as an analysis of the manorial regime in this geograpbical region. We can deduce from our documentation the effectiveness of manorial power, from which the vassals wished to free themselves. Many villages in the manor were to take advantage of this favourable moment to buy their jurisdiction from the King. On the other band the ecclesiastical institutions were to argue before the Crown the harm that these sales would cause them. The opposition of the Cburch explains why the sales would affect only $40 \%$ of the ecclesiastical vassals in Castille-Leon, witbout depleting the quantities that the papal bulls - the legal basis for the sales-permitted. The sale of ecclesiastical jurisdictions was to be very profitable 
for the Crown. The Church on the other hand was to be barmed just like the liberated villages were, many of which were to get into debt and be sold to a Lord.

KEY words: Spain. Castile. 16 th century. Seigneurial regime. Crown-Church Conflicts.

La desvinculación y posterior venta de jurisdicciones eclesiásticas que inicia Carlos V y prosigue Felipe II será un hecho clave en la evolución del régimen señorial castellano a lo largo de la Edad Moderna. La venta de señoríos de la Iglesia es un expediente utilizado por la Corona en el siglo XVI íntimamente relacionado con las dificultades financieras que a los Austrias mayores les ocasiona su ambiciosa política exterior. La monarquía, sin teformar el sistema fiscal, busca ingresos extraordinarios gravando en nuestro caso a la Iglesia.

Los reyes consiguen bulas papales para legalizar sus actos. La bula concedida a Carlos V por Clemente VII el 20 de septiembre de 1529 para desmembrar bienes y vasallos de las Ordenes Militares hasta en cantidad de 40.000 ducados inicia el citado proceso '; posteriormente la bula de Julio III de 1 de febrero de 1551 permitirá desvincular jurisdicciones de monasterios por un valor de 500.000 ducados; finalmente la bula de Gregorio XIII de 6 de abril de 1574 permite vender vasallos de mitras, monasterios y otras instituciones eclesiásticas hasta en cantidad de 40.000 ducados.

El tema, apenas estudiado ${ }^{2}$, se centrará en las desmembraciones y ventas iniciadas en los años setenta y que afecta, como ya dijimos, a todas las instituciones eclesiásticas excepto a las Ordenes Militares; utilizaremos asimismo las conclu-

1 Esta bula fue confirmada por Paulo III el 17 de agosto de 1536, por Paulo IV el 1 de diciembre de 1555, por Pio IV el 1 de diciembre de 1559 y por Pio V el 14 de marzo de 1570; el primero de estos papas expidió breve autorizando tomar hasta 40.000 ducados más. $\mathrm{R}$. Carande estimó en más de un centenar los pueblos de Ordenes Militares vendidos entre 1538 y 1549, subiendo las indemnizaciones que les dieron a unos 37.000 ducados.

2 Para Castilla y León contamos únicamente con: «La venta de vasallos entre el Pisuerga y el Cea en los siglos XVI y XVII» de I. Fernández Martín, Archivos Leoneses, León, 1982; Los señorios de la Iglesia en la tierra de Zamora, siglos XVI-XIX. Los procesos desamortizadores de la riqueza señorial, de A. MORENo SEBASTIÁn, Zamora, 1984 y «Los señoríos eclesiásticos del obispado de Palencia en el siglo XVI", Actas de/ III Congreso de Historia de Palencia, t. II, Palencia, 1997; también hemos estudiado el proceso de desmembración y ventas en el caso de Asturias en nuestra obra Los señorios eclesiásticos en la Asturias del siglo XVI, Oviedo, 1992. Sobre las Ordenes Militares puede verse «Desamortización de tierras de las Ordenes Militares» de J. CEPEDA ADÁN, Hispania, $\mathrm{n} 1$ 146, 1980. Diversos aspectos de las ventas son tratados por $\mathrm{S}$. de Moxó en «Las desamortizaciones eclesiásticas del siglo XVI", AHDE, XXX, 1961 y M. I. Lóplzz DiAz, «Las desmembraciones eclesiásticas de 1574 a 1579 m, Moneday Crédito, 129, 1974.

Hipania, LVIL/3, nưm 200 (1998) 1045-1096 
siones de nuestro trabajo sobre las ventas en tiempo del Emperador ${ }^{3}$, que fueron muchas menos en número. Nos referiremos al espacio castellanoleonés en el que se incluyen los obispados de León, Astorga, Zamora, Salamanca, Ciudad Rodrigo, Palencia, Osma, Calahorra, Segovia, Avila y el arzobispado de Burgos.

Nuestro objetivo será cuantificar el fenómeno señorial antes de las ventas en cuanto a número de enciaves señoriales y de vasallos eclesiásticos, así como estimar cúantos fueron vendidos; nos interesa asimismo analizar la sociología de los compradores, el monto económico de las ventas y el beneficio que le trajeron a la Corona. Precisaremos también el proceso legal seguido en la desmembración de los señorios de sus titulares y en las ventas que tuvieron lugar a continuación, así como el articulado para pagar a los acreedores de la Corona.

Básicamente la documentación utilizada en el trabajo es la generada por la Administración con la finalidad de llevar a cabo las ventas y está localizada en el Archivo General de Simancas. Tenemos, en primer lugar, las averiguaciones generales de distintos obispados ${ }^{4} \mathrm{y}$ las particulares de cada lugar, material de gran interés por la cantidad y calidad de información que aportan. Contamos además con los documentos del proceso legal seguido, así como con las cuentas realizadas en el Consejo de Hacienda para fijar el precio de los lugares que se decidió vender. Las secciones del Archivo consultadas fueron las siguientes: Expedientes de Hacienda, Dirección General del Tesoro, Consejo y Juntas de Hacienda, Contaduría de Mercedes y Escribanía Mayor de Rentas (serie de Mercedes y Privilegios). La documentación conservada sobre este tema no es completa; algunos datos no los podemos conocer a pesar del cotejo de la información de las cinco secciones, pero no obstante es suficiente para la reconstrucción general del proceso.

Dada la rica información que nuestros materiales aportan sobre el régimen señorial castellano evaluaremos su importancia cuantitativa (número de enclaves y vasallos, titulares de los señoríos, reparto geográfico de los mismos) y cualitativa (facultades de los señores y efectividad del poder, tipos de derechos percibidos e importancia económica de los mismos); ello es necesario si tenemos en cuenta que no hay un estudio que a nivel general nos clarifique todas estas cuestiones. Los señotíos castellanos han sido -e incluso son aún hoy - infravalorados y ello ha influido en las pocas investigaciones de que ha sido objeto. Además debemos intentar desentrañar las complejas relaciones existentes entre señorío y propiedad y, muy especialmente, discernir qué señoríos

3 "Los señoríos monásticos de Castilla y León en el siglo XVI" en MARTíNEzz RUIZ, E. y Sú́rez Grimón, V. (eds.), Iglesia y sociedad en el Antiguo Régimen, III Reunión Cientifica, Asociación Española de Historia Moderna, Las Palmas de Gran Canaria, 1994, pgs. 461-482.

4 Contamos con las averiguaciones generales de los obispados de Palencia (Exp. Hac., lg. 353, fol. 8, año 1582 y Cons. y J. de Hac, lg. 132, fol. 2, año 1574), Zamora (Exp. Hac., lg. 442, fol. 1, año 1582 y Cons. y J. de Hac., lg. 131, fol. 3, año 1574), Salamanca (Cons. y J. de Hac., lg. 135, fol. 2, año 1574), Osma (Cons. y J. de Hac., lg. 135, fol. 2, año 1574 y Exp. de Hac., lg. 342, fol. 1, año 1583) y Segovia (Exp. Hac., lg. 386, fol. 1, año 1574). 
son meramente jurisdiccionales y cuáles solariegos, entendiendo por éstos aquellos en los que el señor no solo posee la jurisdicción sino también la propiedad o el dominio directo sobre toda o la mayor parte de la tierra ${ }^{5}$.

Comenzando por el análisis cuantitativo ${ }^{6}$ debemos decir que, tal como se puede ver en el cuadro $A$, el número total de enclaves señoriales eclesiásticos contabilizados en Castilla-León es de $650^{7}$. Y el total de vasallos eclesiásticos es de $40.839^{8}$, lo que viene a suponer de modo aproximado un $10 \%$ de la vecindad total de Castilla-León ?

A las dificultades de concretar el porcentaje de hombres dependientes de la Iglesia respecto a la población total anteriormente a las desmembraciones y ventas se une - de manera redoblada dada la falta de trabajos globales sobre el señorio secular - la de poder conocer qué proporción existe entre señoníos eclesiásticos y seculares y, en definitiva, entre realengo y señorio. Sólo podemos afirmar,

5 Hemos tenido presentes desde el punto de vista metodológico los estudios de S. DE Moxó, especialmente "Los señoríos, cuestiones metodológicas que plantea su estudio», AHDE, XLIII, 1973 y de B. CLAVERO «Señotío y hacienda a finales del Antiguo Régimen en Castilla", Moneda y Crédito, 135, 1975

6 Para realizar la cuantificación hemos tenido que partir de algunos supuestos dada la laguna que nos queda en los obispados de los que no se conserva averiguación general, especialmente el de Astorga, donde además se vendieron pocos lugares y no disponíamos por estas razones de información completa sobre enclaves y vasallos. En estos casos hemos supuesto que los lugares que poseen las instituciones eclesiásticas en el siglo XVIII - según datos del nomenclator de Floridablanca-ya eran suyos en el s. XVI, lo cual es lo más probable. Por otro lado, en cuanto a la cuenta de enclaves y vasallos monásticos las cifras dadas representan un mínimo, potque es posible que quede algún lugar sin contabilizar.

7 En la contabilidad de los enclaves de señorio debemos tener en cuenta que hay lugares de muy diversa vecindad, desde pequeños núcleos hasta concejos o villas con importante población, tal como podemos ver en los cuadros del anexo I.

8 No conocemos el criterio seguido por obispos y corregidores en los recuentos de población - a veces meras estimaciones - que enviaron a S.M., aunque lo más frecuente es contar a los vecinos casados, viudas y clérigos y no a los huérfanos ni a las mujeres solteras. Cuando no disponíamos de estos recuentos hemos utilizado los realizados para vender los lugares en los que se contaban los pecheros y los huérfanos menores de un matrimonio pechero como un vecino; $y$ las viudas, clérigos y huérfanos hidalgos como medio vecino. En el caso de los enclaves que no se vendieron, a falta de las informaciones anteriores, hemos usado los datos de vecindad del censo de 1591 (Censo de Castilla de 1591, Vecindarios, Madrid, 1984) y los recuentos que mandaron los obispos a S.M. en 1587. En cuanto a los lugares de monasterios, los datos de población corresponden a las averiguaciones que para venderlos se hicieron los años 1553 1554. Dada la'escasez de información demográfica hemos utilizado datos de fechas diversas; somos conscientes de la falta de homogeneidad de los mismos, aunque pertenecen a fechas en las que la población se mantuvo en general estabilizada; es en los años ochenta cuando la población comenzó a disminuir en Castilla.

9 El número de vecinos de Castilla la Vieja y León (incluida Cantabria y la Rioja) según el censo de 1591 es de 471.750. J. NADAL, La población española (siglos XVI a XX), Barcelona, 1984. Los tecuentos de población enviados por los obispos de Castilla-León a S.M. en 1587 suman 376.493 vecinos (Censo de Población de las provincias y partidos de la corona de Castilla en el siglo XVI, Madrid, 1829).

Hliptania, LVIII/3, núm. 200 (1998) 1045-1096 
CUADRO A. Enclaves y vasallos eclesiásticos de Castilla-León antes de las desmembraciones

\begin{tabular}{|l|c|c|c|c|c|c|c|c|}
\hline \multirow{2}{*}{ Provincias } & \multicolumn{2}{|c|}{ Mitras } & \multicolumn{2}{c|}{ Monasterios } & \multicolumn{2}{c|}{$\begin{array}{c}\text { Otras } \\
\text { Instituciones }\end{array}$} & \multicolumn{2}{c|}{ Totales } \\
\cline { 2 - 10 } & Enclaves & Vasallos & Enclaues & Vasallos & Enclaves & Vasallos & Enclaves & Vasallos \\
\hline León & 61 & 4.443 & 122 & 4.502 & 23 & 1.305 & 206 & 10.250 \\
\hline Zamota & 21 & 2.899 & 18 & 460 & 7 & 121 & 46 & 3.480 \\
\hline Salamanca & 23 & 4.863 & 2 & 114 & 7 & 181 & 32 & 5.158 \\
\hline Valladolid y & 23 & 2.182 & 59 & 2.260 & 10 & 964 & 92 & 5.406 \\
\hline Palencia & 19 & 682 & 147 & 5.907 & 25 & 1.137 & 191 & 7.726 \\
\hline Burgos y & 2 & 342 & 29 & 3.297 & - & - & 31 & 3.639 \\
\hline Santander & 19 & 1.361 & 6 & 387 & - & - & 38 & 1.748 \\
\hline Sogroño & 6 & 1.609 & - & - & - & - & 6 & 1.609 \\
\hline Segovia & 6 & 1.823 & - & - & - & - & 8 & 1.823 \\
\hline Avila & 195 & 20.204 & 383 & 16.927 & 72 & 3.708 & 650 & 40.839 \\
\hline TOTALES & & & & & & & & \\
\hline
\end{tabular}

mientras no se hagan estos estudios, que el peso del señorío secular es mucho mayor que el eclesiástico; todas las investigaciones destacan la fuerte señorialización de nuestra zona desde fines de la Edad Media y durante la época de los Reyes Católicos, lo que ayuda a explicar las tensiones y fuerte conflictividad existente entre vasallos y señores a comienzos de la Edad Moderna ${ }^{10}$.

Los únicos datos precisos disponibles se refieren al siglo XVIII. Si utilizamos la información aportada por el nomenclator de Floridablanca, los lugares poblados de realengo en Castilla y León son, según nuestro propio recuento, un $36 \%$ y los de señorio un $64 \%$, destacando el señorio secular con un $56 \%{ }^{11}$. La importancia cuantitativa del régimen señorial en el s. XVI es, sin duda, menor que en

10 Aparte de los estudios de diversos medievalistas, en especial de J. Valdeón, debemos destacar YUN CASAL.JILA, B., Sobre la transición al capitalismo en Castilla. Economia y sociedad en Tierra de Campos, Salamanca, 1987 y GuTYéRREZ NiEYO. J.I., Las comunidades como movimiento antiseñorial, Barcelona, 1973.

11 Nomenclator de las ciudades, villas, lugares, aldeas granjas, cotos redondos, cortijos y despoblados de España, Madrid, 1789. Según G. Anes, de un total de 347.750 casas en Castilla-León en 1797 son de señorio 189.741 , lo que supone un $54,6 \%$ del total; no obstante, debemos decir que en estos datos falta la información sobre el reino de León. ANES, G., La España del Antiguo Régimen. Las Borbones., Madrid, 1975. 
el siglo XVIII ya que los señoríos laicos aumentaron a lo largo de la Edad Moderna tanto a costa de los señoríos de la Iglesia como del realengo ${ }^{12}$.

Del total de vasallos eclesiásticos existentes antes de las desvinculaciones del siglo XVI un $50 \%$ son de mitras, un $41 \%$ de monasterios y un $9 \%$ de otras instituciones. Obispos y monasterios destacan nítidamente entre las instituciones eclesiásticas como titulares de señoríos y aunque en cuanto a número de enclaves son superiores los monasterios, generalmente son entidades rurales de poca población, mientras que las mitras poseen villas o concejos con mayor vecindad. La mayoría de los titulares de jurisdicciones son instituciones ubicadas en Castilla y León, mientras que tienen poco peso los titulares foráneos ${ }^{13}$. Igualmente, las instituciones eclesiásticas castellano-leonesas apenas tienen vasallos fuera de nuestra región ${ }^{14}$. La especificación de esta información puede verse en los cuadros I, anexos al presente trabajo.

En cuanto al reparto geográfico de vasallos eclesiásticos debemos destacar un mayor número en la zona norte de Castilla-León (obispados de León y Astorga y arzobispado de Burgos), mientras que va disminuyendo --especialmente en lo que se refiere a los monasterios-s según vamos hacia el sur. Hay que tener en cuenta también que las mitras de León poseen más vasallos que las de Castilla la Vieja (14.387 vecinos frente a 5.817); en contrapartida los monasterios castellanos de Burgos y la Rioja totalizan más de la mitad de los vasallos monásticos (9.204 de un total de 16.927).

Respecto a las facultades de los señores y derechos jurisdiccionales que perciben debemos decir que no tenemos información exhaustiva de todos los lugares, sino únicamente de una parte de ellos; los datos para el análisis de esta cuestión están en las averiguaciones generales y particulares de cada lugar o bien en los resúmenes que hizo la Administración para conocer la cuantía de derechos jurisdiccionales de los lugares a vender y que debía indemnizar. Contamos sobre todo con documentación de los lugares enajenados y de aquellos en los que se inició el proceso aunque luego no fueron vendidos; de cualquier modo la muestra es suficiente para sacar conclusiones generales.

Los señores tienen prerrogativas importantes ${ }^{15}$. En primer lugar dictar ordenanzas, facultad que, cuando no la comparten con los pueblos, interfiere de

12 Gentul DA Silva considera que se vendieton en la corona de Castilla entre 1626 y 1668 unos 52.306 vecinos, de los que 32.224 pasaron a señorio y el resto se compraron los propios vecinos (Desarrollo económico, Subsistencia y Decadencia en España, Madrid, 1967, pgs. 223-224). A. DomíN. GUEz ORTIZ da cifras parecidas en el estudio "Ventas y exenciones de lugares durante el reinado de Felipe IV", que puede verse en su obra Instituciones y saciedad en la España de los Austrias, Barcelona, 1985.

13 Hay que citar en este sentido al arzobispo de Santiago, el arzobispo de Toledo y el obispo de Oviedo con un total de $2.078,5$ vasallos y a los monasterios de Valdediós, Corias y Roncesvalles con 203 vasallos.

14 El obispo de Segovia tiene 669 vasallos en Madrid y los monasterios castellano-leoneses únicamente tienen fuera de nuestra zona 4 lugares con un total de 195 vecinos; en total son 864 vasallos.

15 Nos referiremos siempre a aquellos lugares en los que el señor tiene la jurisdicción, es decir atribuciones de carácter público tales como ejercer la justicia y el nombramiento de ofi-

Hispania, LVIII/3, núrn. 200 (1998) 1045-1096 
modo importante la vida de los mismos. Otra competencia básica es la de ejercer justicia civil y criminal en sus lugares jurisdiccionales; tienen, sobre todo, el derecho de apelación, el cual ejercen de manera efectiva. En este sentido, las facultades judiciales de los señores se habían visto mermadas por el derecho superior de justicia del monarca, ante cuyas justicias y tribunales podian ir los vasallos (nuestras fuentes explicitan que pueden acudir a la chancillería de Valladolid o al Alcalde del Adelantamiento, a elección del apelante); no obstante, la intimidación de los señores para que no fueran — nos constan ejemplos suficientes- así como los gastos que ello suponía nos hace pensar que no debía ser muy ejercido este derecho, al menos por cada vasallo particularmente. Mucho más frecuente era el recurso colectivo de los lugares de señorio al rey y sus tribunales solicitando reducción de derechos señoriales o protestando de los abusos del señor.

Otra atribución de los titulares de señorío es el nombramiento de los oficios concejiles: ponen un alcalde mayor - que suele ser común para todos o para varios de sus lugares - y los oficios del lugar (alcaldes ordinarios, regidores, alguacil, procurador general). Los alcaldes ordinarios del concejo ejercen jurisdicción en primera instancia; el alcalde mayor también, aunque solamente cuando va a visitar el lugat, lo que hace generalmente una vez al año.

En muchos lugares hay costumbre de que en el nombramiento de los oficios del concejo participen los vecinos; en otros no. Éste será un motivo frecuente de conflicto entre señores y vasallos. El sistema autoritario coexiste con diversas fórmulas de participación de los habitantes de señorío: nombramiento por el concejo y confirmación del señor; elección de los nuevos magistrados por los cargos salientes; nombramiento de oficios doblados por los vasallos y elección de la mitad de ellos por el titular. A pesar de lo lacónico de nuestras fuentes debemos decir que lo más frecuente es la existencia de alguna fórmula de participación, situación que es general en los señoríos dependientes de las mitras. Esta participación se suele concretar en el nombramiento por el lugar de varias personas entre los que el señor elige algunas de ellas, generalmente la mitad. En ocasiones este sistema se sigue para la elección de los jueces ordinarios, mientras que la del resto de los oficios la hacen los vecinos con sólo la confirmación del señor. También sabemos —aunque no siempre se explicitaque con mucha frecuencia no son todos los vecinos los que intervienen en la

cios. No nos referiremos a aquellos otros en los que un señor percibe rentas señoniales $y_{1}$ a veces, tiene una jurisdicción minima - no superior a $100 \mathrm{mrs}$ - que ejerce a través de un merino, hecho frecuente en algunas zonas de Castilla. A través de las averiguaciones de los lugares monásticos hemos constatado esta situación muy a menudo en la zona norte de Castilla la Vieja (Burgos y La Rioja). Descartamos, por tanto, el «señorio territorial» que establece Moxó ya que creemos que la posesión de la jurisdicción por el señor es una característica básica del señotio. Igualmente B. ClAvEro ( SSeñorio y hacienda a finales del antiguo régimen en Castilla», Moneda $y$ Crédito, 135, 1975, pg. 115) considera que la distinción de Moxó entre «señotío territorial» y «señorío jurisdiccional», que fue la utilizada en el momento de la abolición de las relaciones señoriales, no es la adecuada para el análisis histórico.

Hipunia, LVIII/3, nüm. 200 (1998) 1045-1096 
elección sino solamente los oficios salientes ${ }^{16}$. De un total de 147 lugares de los que tenemos información, hay participación de los vecinos en 104. Podemos decir además que las villas y concejos de señorío de mayor población gozan siempre de alguna forma de participación ${ }^{17}$.

El gobierno autoritario, la designación directa por el señor sin tener en cuenta la participación de los vecinos, se ejerce en muchos lugares de monasterios (en la mitad de ellos según nuestra muestra) mientras que no consta ningún caso en los enclaves episcopales. El señor pone los oficios por un año generalmente; conocemos 43 pueblos en esta situación ${ }^{18}$. Los lugares donde participan los vecinos representan el $71 \%$, los de gobierno autoritario el $29 \%$. Para Asturias las cifras son parecidas a las de Castilla-León; también allí sucede que son los lugares de la mitra ovetense donde se dan las formas participativas, mientras que en los enclaves monásticos es el señor quien nombra generalmente los oficios ${ }^{19}$.

A pesar de la diversidad del poder señorial según haya o no participación de los pueblos, como dice Guilarte «el poder del señor constituye - digase lo gue se digauna realidad en el siglo $X V T$, ${ }^{20}$. En todos los lugares nombran los señores alcalde mayor -persona de fuera del concejo y en el que delega casi todas sus atribucio-

16 En las villas de mayor población esta situación favorecia a unos pocos, que controlan el gobierno municipal, aunque se puede decir que la existencia de una oligarquia municipal se desarrolla menos en los lugares de señorio que en los pueblos de realengo.

17 Conocemos los siguientes dependientes de mitras, cabildos catedralicios y abadías: Boada, Castrovega, encartación de Curueño, Matallana, Santa Cristina, Villacarlón, Modino, Molinaherrera, Peñamián, Valdeteja y La Braña, Canalejas, Villaverde de Abajo, Castrilino y V1llanueva del Árbol, Fuentes de los Oteros y Grajal en el obispado de León; Cantalapiedra, Mollorido, Vitigudino, Topas, Zofraga, Carrascal, Los Huelmos y Casasola, Tejares, San Pelayo y Palacinos, San Martín del Castañar, Fregeneda, Bermellar, Lumbrales y Aldeanueva del Arzobispo en el obispado de Salamanca; Palacios del Alcor, Santa Cruz de Boedo, Magaz, Villalobón y Ledigos en el obispado de Palencia; Velilla, Ucero, Santuy, Muriel de la Fuente, Muriel Viejo, Cubilla y Talveila en el obispado de Osma; Caballar, Turégano y Veganzones en el obispado de Segovia; Fuentesaúco, Fermoselle, Venialbo, Villamor de los Escuderos, Mayalde, Moraleja de Sayago, Fresno de Sayago, Villalcampo, Manganeses, Almendra, Fresno de la Ribera, Bamba, Sánzoles y Arquillinos en el obispado de Zamora y Badillo de la Sierra en el obispado de Avila. Respecto a los lugares monásticos conocemos la participación en la elección de sus oficiales de 41 lugares.

18 No intervienen los vecinos en los lugares de Toreno y Palaciosmil, así como en otros 41 lugares monásticos. En la villa de Canalejas y en el lugar de Calaveras el monasterio de Sahagún pone juez sin limitación de tiempo; en Argovejo el de Benevivere lo pone por tres años. En San Leonardo el abad de San Pedro de Atlanza nombra jueces y alguacil pero el resto de los oficios deja elegirlos al concejo; lo mismo sucede en Palaciosmil, del atcediano de Ribasdesil y en Tórtoles, del monasterio de su nombre.

19 M. Ángriles FAYA, Las señorios eclesiásticos en la Asturias del siglo XVI, Oviedo, 1992, pg. 149. NOEL SALOMON da para los pueblos de señorío eclesiástico de Castilla la Nueva cifras un poco distintas: el 38 para las fórmulas participativas y el $62 \%$ para las autoritarias. Ello puede ser debido a la utilización de criterios distintos; si no es así habría quie pensar en un mayor vigor del poder del señor en Castilla la Nueva. La vida rural castellana en tiempas de Felke I, Barcelona, 1982.

20 A.M. GuILARTE, El régimen señorial en el siglo XVI, Valladolid, 1987, pág. 204.

Hitqunia, LVIII/3, núm. 200 (1998) 1045-1096 
nes-, escribano y, a veces, alguacil; ejercen asimismo la prerrogativa de hacer residencia a los oficios salientes y de fiscalizar las cuentas municipales ${ }^{21}$. Pero la dejadez, junto con lo rudimentario del sistema judicial, son a menudo causa de la carencia real de gobierno. La mala administración, además de la lógica arbitrariedad que propicia el sistema, son algunos de los aspectos más negativos del régimen señorial. El alcalde mayor del Adelantamiento de Castilla en el partido del reino de León, en la averiguación que manda a la Administración en 1553, recomienda al príncipe Felipe que

"por lo que yo tengo entendido e bisto de algunos de los dichos monesterios me paresge que conbiene al servigio de nro. señor dios y al de su mg. e de vra. ala. que ellos no tengan juresdiscion en estos lugares porque demas de distraerse de sus obras e ofigios no se bafe ni administra justigia en casa que entre sus basallos se ofrescos ${ }^{22}$.

Otro de los atributos de la soberanía señorial es la percepción de tributos y derechos. En nuestra documentación, la Administración distingue con toda claridad las rentas que los señores perciben por vía jurisdiccional -ya que en los lugares que se vendiesen habría que indemnizar a sus titulares-, de lo que llama «rentas temporales», derivadas del derecho de propiedad y que, por tanto, no se habrian de desmembrar. Debemos tener en cuenta que lo que se desvincula y aparta de las instituciones eclesiásticas en base a las bulas de 1551 y 1574 es únicamente la jurisdicción y nunca los bienes raíces - salvo las fortalezas-, a diferencia de lo que sucedió con los pueblos desmembrados de las Ordenes Militares. Este discernimiento de la Administración nos ayuda de forma importante en el análisis del imbricado tema de los derechos percibidos por los señores. Aunque no siempre fue fácil y hubo de pronunciarse la Junta de Presidentes sobre derechos confusos, los conceptos legales adoptados nos ayudan a clarificar cuestiones polémicas sobre nuestro tema, tanto conceptuales como metodológicas ${ }^{23}$.

Entre los derechos que tienen por vía jurisdiccional están, en primer lugar, los derivados del ejercicio de la justicia; una parte de las penas pecuniarias las percibían las justicias del lugar; otras eran para el señor (penas de cámara), las cuales procedian básicamente de las sentencias dictadas por el alcalde mayor en

21 En Grajal, Gusendos y Vitigudino el señor no tiene derecho a hacer tesidencia; en este último lugar tampoco lo tiene a tomar las cuentas al concejo puesto que es atribución de los jueces salientes. Los tres lugares tienen pleito en la Chancillería dado que no se les tespeta este derecho.

22 A.G.S., Diversos de Castilla, 47, 31

23 «Rentas jurisdiccionales» son las satisfechas por el vasallo por su condición de tal mientras que las «rentas temporales» tienen su origen en el marco de las relaciones privadas contractuales, teniendo derecho el propietario a modificarlas al finalizar el plazo del contrato. Las «rentas jurisdiccionales», al contrario, son derechos fijados de modo perpetuo - uno suben ni bajan?-, a no ser tras un acuerdo del señor con sus vasallos; y generalmente, aunque no siempte, son cantidades señaladas para el conjunto de los vecinos.

Hipania, LVIII/3, núm. 200 (1998) 1045-1096 
su visita anual. Además de estos derechos los titulares llevan otros sobre las personas derivados de las prerrogativas públicas que tienen. Tenemos también otros conceptos cuyo origen está en los derechos que el señor conserva sobre algunos o todos los bienes del lugar (tierras, pastos, pesca, etc.). De cualquier modo determinar el origen y la naturaleza de los derechos jurisdiccionales del señor no siempre es fácil puesto que de algunos de ellos no se sabe ya en el siglo XVI por qué motivo se satisfacen y en otros casos, prestaciones en trabajo y en especie - a veces varios conceptos conjuntamente- fueron conmutados a una cantidad en dinero, perdiéndose así su sentido originario ${ }^{24}$.

Para conocer el tipo de derechos que satisfacen los vasallos eclesiásticos de Castilla-León en el siglo XVI partiremos de una muestra de 283 lugares (167 son enclaves monásticos y 116 de mitras y otras instituciones eclesiásticas), que es de los que tenemos la información pertinente ${ }^{25}$. Los derechos, por orden de frecuencia, son los siguientes:

\author{
Martiniega: 86 \\ Yantar: 66 \\ Fueros y otros derechos de señorio: 39 \\ Prestaciones de trabajo: 34 \\ Presente navideño y/o pascual: 32 \\ Infurción: 29 \\ Humazgo: 23 \\ Detechos de pesca y/o caza: 13 \\ Derecho de paso de mercancías y/o ganados: 10 \\ Derecho de uso de montes y/o pastos: 5 \\ Derecho de confirmación de oficios: 5
}

Del análisis de los datos de esta muestra podemos deducir que los derechos derivados del señotio sobre las tierras (martiniega, infurción, fueros ) y las casas o sus solares (humazgo) suponen más de la mitad del número total de dere-

24 Aunque los documentos legales hacen constantemente alusión a que el señor posee el señotio, la jutisdicción y el vasallaje, no se delimitan los derechos que percibe por cada uno de estos conceptos. Otras veces señoxio y vasallaje se usan indistintamente, por lo que el concepto de vasallaje que establece Moxó no es válido. Como dice Tomís y VALIENTE en su recensión a la obra de $S$. de Moxó $L$ a disolución del régimen señorial en España, elel intento de conceptualizar a posterion lo que en su época no se conceptualizó resulta una empresa enormemente arriesgadas (AHDE, XXXV, 1965, pg, 614).

25 Debemos tener presente que no se ha podido contabilizar algunos derechos cuya naturaleza no estaba clara. También debemos tener en cuenta que algunos lugates no pagan ningún derecho por vía jurisdiccional, a excepción de las penas de cámata; esto último sucede en 58 lugares de monasterios y en algunos otros de otras instituciones. Respecto a los mostrencos (derecho sobre los ganados perdidos) es un derecho contabilizado para indemnizar a los titulares en las ventas de señonios llevadas a cabo por Felipe II, pero no fue asi'en las ventas de tiempos del Emperador por lo cual en esa fecha ni siquieta se averiguaton. Por los datos que tenemos podemos decir que este derecho no lo tenían todos los titulates de serioríos castellano-leoneses, perteneciendo a veces a la Mesta.

Hipania, LVIIJ/3, núm. 200 (1998) 1045-1096 
chos satisfechos por los hombres de señorio, especialmente si tenemos en cuenta los procedentes del uso de baldíos y comunales (montes, pastos, pesca) ${ }^{26}$. Son vestigios del dominio antiguo que sobre la tierra tenían los señores; pero también expresan la crisis de la propiedad feudal en unos señoríos que se pueden considerar ya en este momento de forma mayoritaria meramente jurisdiccionales, como luego veremos.

Si de los derechos sobre las tierras pasamos a los derechos jurisdiccionales sobre las personas debemos decir que las cargas más frecuentes son el yantar (generalmente conmutado a dinero) y el presente navideño. Son derechos simbólicos derivados del acatamiento al señor y suponen cantidades poco importantes para el vasallo, al igual que sucede con los derechos anteriores. Meramente testimoniales en Castilla son los relativos al paso de mercancías o ganados; no quedan vestigios de monopolios señoriales sobre el molino, horno o lagar y otros derechos de origen feudal también han desaparecido prácticamente.

Los derechos por vía jurisdiccional son satisfechos unos en especie (generalmente en trigo-cebada o en trigo-centeno) y otros en dinero; este último caso es el de la martiniega, del humazgo y del yantar, que tienden a devaluarse con el tiempo. En algunos señorios se exigen prestaciones de trabajo y expresan la antigua o actual condición solariega de los vasallos. Aunque son residuales, conservan cierta importancia en los señoríos monásticos pero reguladas y reducidas a unos pocos días al año (entre 1 y 6 días generalmente); no quedan en Castilla-León servicios a voluntad a diferencia de lo que sucede a veces en Galicia y Asturias. Con una muestra de 261 enclaves monásticos solo hacen prestaciones de trabajo 64 lugares $(24,5 \%)$ con un total de 2.844 vecinos $(21,5 \%)^{27}$. La satisfacción de corveas por los vasallos monásticos no es muy frecuente aunque tampoco despreciable; menos importantes son para el resto de vasallos de la Iglesia ya que solo nos constan en estos cuatro lugares: los vecinos de las aldeas de Fermoselle deben ir a cazar uno o dos días para el

26. Estos pagos, que satisfacen todos los vecinos generalmente, hay que diferenciarlos de otras rentas territoriales derivadas de relaciones privadas y pagadas a titulo individual, procedentes de contratos de corto (arrendamientos) o latgo plazo (censos enfiteúticos o foros). B.Clavero distingue a este respecto rentas del señorio estricto o dominio señotial y urentas de la heredads o del dominio eminente; N.Salomon, por su parte, habla de propiedad territorial señorial y propiedad territorial no señorial. En el caso concreto de la infurción debemos decir que la pagan sólo algunos lugares monásticos; así nos consta en lugares dependientes de los monasterios de Nájera, Oña, San Pedro de Arlanza, Santo Domingo de Silos, San Pedro de Cardeña, Las Huelgas de Burgos, San Andrés de Arroyo, Bugedo, Villena, Aguilat de Campoo y Santo Domingo de Caleruega. En cuanto a los derechos sobre montes, pastos, caza o pesca, son exigidos sobre todo por algunos monasterios; sobre esta cuestión debernos precisar que en ocasiones el uso de bienes comunales también está sometido a restricciones, prohibiciones e imposición de penas a los vecinos en caso de incumplimiento.

27 Las prestaciones pueden ser bien personales, generalmènte de acarteo, bien de trabajo en las tierras del señor, nos demuestra en este caso cómo en algunos monastetios la teserva medieval no ha desaparecido. 
obispo de Zamora y los de la aldea de Cibanal deben hacer además tres días de labor al año con sus bueyes a favor del alcaide de la fortaleza de la villa; en la villa de Manganeses los vecinos que tengan bestia deben llevarle el pan que dicho obispo tiene en esta villa hasta la ciudad de Zamora; los pueblos de Valdeteja y La Braña deben pescar para el obispo de León, dándoles únicamente de beber.

Una clasificación los señoríos es necesaria dada la amplia casuística existente incluso dentro de una misma región; permite sobre todo diferenciar situaciones de mayor o menor avance en su proceso de desintegración. Podemos distinguir en Castilla dos tipos de señoríos: los meramente jurisdiccionales que son los más frecuentes- en los que el titular posee la jurisdicción, mientras que la tierra pertenece a diversos propietarios y los solariegos, donde los señores además de la jurisdicción conservan el dominio directo o tienen la propiedad plena sobre toda o la mayor parte de la tierra; éstos son residuales en Castilla ya que solo perviven en algunos lugares de monasterios ${ }^{28}$. De un total de 261 enclaves monásticos de los que tenemos información y que suman 13.234 vecinos solo son solariegos 59 lugares, que representan el $23 \%$ de la citada muestra; si tenemos en cuenta la vecindad debemos decir que el porcentaje disminuye: los 1.714 vasallos solariegos sólo son el $13 \%$ del total. Si la condición solariega es meramente residual en los señorios de monasterios, en los de las mitras es inexistente; y en cuanto a otras instituciones eclesiásticas solo nos constan como tal 8 lugares: tres de ellos dependientes del deán y cabildo de la catedral de Salamanca y otros cinco del deán y cabildo de la catedral de Zamora ${ }^{29}$.

En los señoríos solariegos podemos distinguir dos situaciones: alli donde el lugar está despoblado y es explotado directamente por el titular de la jurisdicción o arrendado a una persona, que es el caso de algunos lugares de monasterios y cabildos catedralicios ${ }^{30}$. Otros lugares, en cambio, están poblados; hay

28 No obstante, debemos aclarar que en los señorios que hemos denominado meramente jurisdiccionales es bastante frecuente que los señores tengan algunos bienes.

29 Son los lugares de Buenamadre, San Cristóbal del Monte, Mercadillo, San Román, San Julián, Mazares, Congosta y Valverde; éstos tres últimos son dehesas y están despobladas.

30 Nos consta esta situación en los cuatro citados del deán y cabildo de Zamora y en los lugares donde están ubicados los monasterios de La Espina, Benavides, Retuerta y San Isidro de Dueñas, así como los lugares monásticos de El Cubeto, Moreruela, y cuatro dehesas del monasterio de San Jerónimo de Zamora; en total son 14 lugares. Sabemos que el monasterio de La Espina despobló el coto donde estaba ubicado el monasterio a lo largo del siglo XV y explota la tierra directamente, considerando la tierra más rentable que los vasallos, lo cual tiene su lógica en un siglo de alza de los precios agrarios, teniendo en cuenta además que subir las tentas a los vasallos podía ser dificil o al menos problemático. J.M. LOPEZ GARCiA, La transiaión del feudalismo al capitatismo en un señorio monástion castellano. El abadengo de la Santa Espina, Valladolid, 1990, pgs. 46-52. El preferir la tierra a los vașallos es una estrategia todavia minoritaria, pero posteriormente va a ser más frecuente. El nomenclator de Floridablanca da para fines del s. XVIII un total de 7.548 lugares en Castilla-León entre los que hay 1.044 granjas, dehesas y despoblados en genetal que suponen el $14 \%$ del total de lugares; de ellos 555 son de realengo, 337 de señorío secular, 118 de señorio eclesiástico y 34 de las

Hispania, LVIII/3, núm. 200 (1998) 1045-1096 
vasallos - a los que se llama solariegos - que bien tienen la tierra cedida de forma consuetudinaria (censos enfiteúticos, foros) por la que satisfacen derechos jurisdiccionales y rentas; bien la llevan en arrendamiento a corto plazo y pagan únicamente rentas.

Podemos concluir que el señorío solariego de origen medieval, en el que propiedad y jurisdicción estaban íntimamente imbricadas, está en descomposición en el siglo XVI. Pero la evolución en algunos casos favoreció al señor, que aftanzó la propiedad sobre las tierras, las cuales posteriormente explota directamente o arrienda a sus vasallos ${ }^{31}$. Generalmente los señoríos solariegos evolucionaron a lo largo de la Edad Media, siendo ya en nuestro siglo meramente jurisdiccionales. Propiedad y jurisdicción tienden a disociarse, al mismo tiempo que muchos señores están elaborando nuevas estrategias que les permiten no ver disminuídas sus tentas.

Podemos decir que los derechos que pagan los vasallos de las mitras son de menor contenido económico que los de los monasterios; son los titulares monásticos los más atentos y más exigentes en la defensa de sus rentas. No obstante en ninguno de los casos significan demasiado; utilizando la muestra de lugares vendidos, cuyas rentas jurisdiccionales evaluó la Administración para indemnizar a los titulares afectados, nos sale una media de unos $50 \mathrm{mrs}$ lo que paga cada vasallo al señor ${ }^{32}$, cifra poco importante si la comparamos con otras detracciones a las que están sometidos, como son la renta de la tierra y los diezmos.

Tampoco para los señores suponen demasiado si las comparamos con sus rentas totales ${ }^{33}$, aunque los monasterios que poseen muchos señorios (Las

órdenes militares. Sin duda, la dificil situación por la que atraviesa el campesinado castellano en el siglo XVII es un elemento a tener en cuenta en la constitución de estos señorios solariegos sobre despoblados; los señores, al desaparecer los vasallos consolidan la propiedad sobre la tierta, al mismo tiempo que mantienen la jurisdicción. Pero también algunos grandes propietarios comptan la jutisdicción al rey y constituyen un señorio, lo que es una buena táctica para poder cobrar las rentas de sus tierras.

31 Son sobte todo lugares de los monasterios leoneses y zamoranos los que no pagan nada por vía jurisdiccional sino por renta de la tierra. Es posible que algunos señores lograsen afirmar su propiedad cambiando por rentas los derechos sobre la tierra que percibían por vía jurisdiccional, tal como hizo el monasterio asturiano de Belmonte; algunos monasterios tienen especial interés en hacer constar que sus vasallos son arrendatarios y que pagan tentas y no derechos jurisdiccionales. Así sucede con los de San Prudencio, San Andrés de Arroyo y Sandoval, mientras el de Castañeda cita expresamente el desahucio. No obstante, lo más frecuente es el pago combinado de derechos jurisdiccionales y de rentas de la tierta por parte de los vasallos eclesiásticos tanto los dependientes de mitras, monasterios y otras instituciones.

32 La media en el obispado de Segovia es de 21,5, mrs/vecino; en el de Avila de $24 \mathrm{mrs}$; en los de Burgos/Calahorra de 36; en los de León/Astorga 37; en el de Palencia 43; en los de Salamanca/Ciudad Rodrigo 57; en el de Zamora 58,5; en el de Osma $117 \mathrm{mrs} /$ vecino. N. SALOMÓN también estima cantidades similares para las cargas señoriales que paga cada vasallo en Castilla la Nueva: La vida rural castellana en tiempos de Felipe II, op. cit., pgs. 215-220.

33 Los ingresos derivados de diezmos son importantes para las mesas episcopales y para algunos monasterios. Según A. GARCía SANZ más del $90 \%$ de los ingresos que percibe el obispo de Segovia en el siglo XVIII procede de los diezmos; lieva el $17,4 \%$ del total de todo lo 
Huelgas de Burgos, Oña, San Benito de Sahagún) reciben en total cantidades importantes. Para el obispo de Palencia los derechos jurisdiccionales suponen aproximadamente un $1 \%$ del total de rentas que percibe; igualmente los obispos de Segovia y de Salamanca - si nos atenemos a la información de las averiguaciones generales- reciben respectivamente $57.788 \mathrm{mrs}{ }^{34}$ y 195.814 $\mathrm{mrs}$ por vía jurisdiccional, lo que viene a representar en el primer caso un $0,7 \mathrm{y}$ en el segundo un $2 \%$ del total de rentas episcopales ${ }^{35}$.

No obstante, nos consta que la lucha entre señores y vasallos fue continua en algunos casos. Mientras aquéllos intentan aumentar su beneficio económico o al menos conservarlo, las comunidades aldeanas intentan mantener su situación y, si es posible, mejorarla. Los hombres de señorío se niegan en ocasiones a pagar ciertos derechos o tratan de impedir restricciones que les ponen sobre el uso de comunales, se quejan y recurren ante los tribunales reales. Alegan a veces que las cargas son nuevas, que son "imposiciones» y que no se respetó la costumbre; o bien que se les aumentó la cantidad exigida, lo que no podían hacer los señores por ser los derechos jurisdiccionales cantidades fijadas de modo perpetuo. En otras ocasiones la conflictividad deriva de las atribuciones jurisdiccionales en sentido estricto y, muy especialmente, del nombramiento de los oficios del lugar; los vasallos llegan a veces a cuestionar la misma jurisdicción señorial.

Los monasterios adoptan una postura más dura con sus vasallos, por lo cual los enfrentamientos son más frecuentes en los lugares monásticos; al contrario, la situación es mucho más tranquila en los señoríos episcopales. Podemos decir, pues, que las estrategias seguidas por algunos señores son variadas: aumentar el monto de las cargas percibidas e introducir otras nuevas; transformar derechos jurisdiccionales derivados de sus derechos sobre la tierra, que eran cantidades fijas en el tiempo y por tanto devaluadas, en rentas de la tierra, renovables y que suponían cantidades mayores; incluso usurpan o tratan de controlar los comunales. $\mathrm{Y}$ con el objetivo de obtener mayor rentabilidad de

diezmado en el obispado (Desarrollo y crisis del Antiguo Régimen en Castilla la Vieja, Madrid, 1986, pgs. 314-315). Puede verse también M. BARro Gozalo, Estudio socioeconómico de la iglesia de Segovia en el siglo XVIII, Segovia, 1982.

34 En esta cifra no están inclú́dos los derechos jurisdiccionales que percibe en la villa de Mejorada, que desconocemos.

35 Todas las investigaciones corroboran la escasa importancia de los derechos señoriales percibidos por los señores tanto laicos como eclesiásticos. No obstante, no se incluyen en muchas ocasiones otras percepciones en sus jurisdicciones no propiamente señoriales, tales como censos enfiteúticos, diezmos, alcabalas u otro tipo de rentas de origen no feudal, lo que también habria que tener en cuenta a la hora de evaluar su beneficio económico. En este sentido, Mazautic considera que hay que recurrir a métodos de análisis más globales y que si se juzga por su función económica, la distinción entre diezmo, derechos feudales e incluso renta de aparceria o arrendamien to desapatece para dar paso a la noción de contribución global; lo que interesa es si ayuda a modificar o, por el contrario, a perpetuar el antiguo sistema. En el mismo sentido, Soboul cree que se falsea la realidad si sólo se incluyen los impuestos propiamente señoriales (La abolición del feudalismo en el mundo occidental, Madrid, 1979, pg. 237).

Hispania, LVIII/3, núm. 200 (1998) 1045-1096 
sus señoríos, algunos señores consiguen despoblar el lugar para explotar directamente la tierra o arrendarla temporalmente, como ya dijimos. También los monasterios recurren ante los tribunales reales para defender la jurisdicción amenazada en ciertos lugares ${ }^{36}$.

Sabemos del malestar de los hombres de señorío ante su situación y prueba evidente de ello es, como veremos, el deseo unánime de pasar a ser de realengo con ocasión de las ventas que pensaba efectuar la Corona. En este sentido podemos aducir la información que da el alcalde mayor del Adelantamiento de Castilla en el reino de León a la Administración en 1553 sobre los señoríos de monasterios; dice:

"Los basallos de todos los monesterios que ban en la memoria desean no ser dellos e ynfinito por serlo de su mg. e si no tubiesen temor que los mesmos monesterios los abian de conprar tratarian ellos de conprarse para si e si desto t. al'. fuere mas sabido con mandarles abisar e gerteficar que no se an de bolberpor ningun prę̧io a los monesterioss ${ }^{37}$.

Algunos pueblos se comprarán —o al menos lo intentarán- en ese momento, lo mismo que los lugares de otras instituciones eclesiásticas tras el

36 Nuestra documentación ofrece únicamente información circunstancial sobre pleitos y conflictividad en general; sería interesante estudiar esta cuestión con documentos más específicos. Sin embargo nos consta que los monasterios defienden con tesón su jurisdicción frente a la nobleza, jueces reales, ciudades y villas de realengo; contamos con muchos ejemplos en este sentido. Igualmente nos consta que señores y vasallos pleitean o bien éstos se quejan al juez averiguador de diversos abusos. Asi sucede en los lugares de El Cubo (monasterio de Valparaiso), Aguas Candias, Solas, Mijangos y Penches (monasterio de Oña), Somalo, Villarrica y Santurdejo (monasterio de Nájera), tierra de Tudela (monasterio de Santa Clara de Pomar), Villamuera (monasterio de San Zoilo de Carrión), Pazuengos y valle de San Millán (monasterio de San Millán de la Cogolla), Sardón (monasterio de Retuerta), Almaraz (monasterio de San Elifonso de Toro), Tórtoles (monasterio de Tórtoles); Fuentelcésped y Fresnillo de las Dueñas (monasterio de La Vid), San Román de los Oteros (monasterio de San Clodio), Argovejo (Benevivere), Manganeses (obispo de Zamora), Villadangos (obispo de León), Gusendos y Grajal (Deán y Cabildo de la Iglesia de León) y Cantalapiedra y Vitigudino (obispo de Salamanca). La situación es especialmente tensa en Fresnillo de las Dueñas: los vecinos se quejan del monasterio en la averiguación particular realizada en 1554; éste inició una reacción señorial hace unos 30 años, exigiéndoles nuevas y múltiples cargas sin título ni escritura alguna por lo que --según los vecinos- no son «derechos» sino (imposiciones). Así, entre otros derechos, les pide ntor via de impasicion y con colores injustos sin saber ninguna justicias un obrero y cuatro cargas de pan a cada vecino al año, así como les obliga a traet 15 fanegas de sal de Medinaceli cpor fuerza y contra su voluntad apremiándoles y poniendoles pena a que fuesen por ello porque los vecinos no se la querian traer porqute decian que no se lo debian;; alegan que lo hacen por fuerza y por miedo ya que les llevan presos. A.G.S., Exp. Hac., lg. 276, fol. 5. Pero la intimidación para que los vecinos no pleitearan debió ser frecuente. También hay quejas ante el Consejo de Hacienda de los hugares que pretenden comprarse o acogerse al derecho de tanteo si ya habían sido comprados por un nuevo señor: dicen que son atemorizados por esta razón y sometidos a prisiones y malos tratamientos por los antiguos o nuevos titulares o bien por otros poderosos que pretendían la compra. Nos consta que así les sucedió a los lugares de Santa Cristina, Arbás, Congosto, Peñamian, San Román de los Oteros, Olivares, Mazariegos, Pozuelo de Belmonte, Fuentesaúco, Fregeneda, Zofraga, Canalejas y Calaveras.

37 A.G.S.; Diversos de Castilla, libro 47, 31. 
proceso de ventas que inicia Felipe II en los años setenta. Y es que la jurisdicción es un medio de coacción extraeconómica; no sólo debe tenerse en cuenta el pequeño beneficio directo que tenía para los señores y deducir de ello que el señorío era un vestigio del pasado sin otras implicaciones. La jutisdicción es un medio por el que algunos titulares de jurisdicciones afianzaron o aumentaron su patrimonio territorial, incluso privatizando baldíos y comunales. Las importantes facultades de gobierno que conservan las utilizan con frecuencia en su propio beneficio y de esto tienen clara conciencia los pueblos, a los que aterra pasar a pertenecer a un particular en el momento de la venta de señoríos eclesiásticos y de manera general inician el proceso de tanteo a pesar de sus pocos recursos económicos ${ }^{38}$.

Otro beneficio que reporta a los señores la posesión de la jurisdicción es el poder cobrar sin problemas sus rentas y diezmos, lo que supone para algunos señores cantidades importantes. Los titulares eclesiásticos poseen a menudo, como ya dijimos, otros bienes rústicos en sus lugares por los que cobran rentas derivadas bien de formas de cesión perpetuas o a largo plazo, bien de arrendamientos a corto plazo; frecuentemente también llevan los diezmos. Será el argumento principal de los monasterios para que no se les quite algunos de sus cotos. A los hombres de señorío no les quedaba, a diferencia del resto de los campesinos, la posibilidad de resistencia pasiva a pagar dichas rentas y diezmos. Tras la redención de Villanueva de San Mancio y de Puerto Santoña los monasterios de Sahagún y Nájera se quejarán de que no pueden cobrar allí sus rentas; esto indica que tenían razón sobre el daño que les traería la pérdida de la jurisdicción. Podemos decir que hay una relación entre la jurisdicción y el elemento solariego en unos señoríos que hemos definido como meramente jurisdiccionales. El régimen señorial se adapta a los nuevos tiempos, evoluciona en Castilla mucho más que en la corona de Aragón, pero conserva parte de sus antiguas funciones; es operativo y, por tanto, no desaparecerá en la Edad Moderna.

El origen del patrimonio rústico citado no podemos conocerlo a través de nuestra documentación, pero proviene bien de donaciones o de compras efectuadas por los señores, bien del afianzamiento de sus derechos sobre la tierra poseída de antiguo, bien de la apropiación de zonas baldías, roturadas y puestas en cultivo frecuentemente en este siglo ${ }^{39}$. Muchos señores reconsti-

38 Seguramente se pensaba que los obispos eran más benévolos que podía serlo la nobleza. Aunque también los monasterios estaban generalmente muy atentos a lograr el máximo beneficio de sus seriorios y sus vasallos desean liberarse de ellos.

39 Es posible que la usurpación de comunales fuera frecuente. Aunque tenemos poca información concreta sobre esta última cuestión referida a Castilla-León, si la tenemos sobre lugares del monasterio de Monsalud (Guadalajara), del que se quejan los vecinos por este motivo. Los señores laicos lo harán muy a menudo. Asi, I. ATIENZA cita apropiación de comunales y baldios por el duque de Osuna en los pueblos sujetos a su jurisdicción: Aristocracia, poder y riqueza en la España moderna La Casa de Osuna siglos XV-XIX, Madrid, 1987, pgs. 138-141. El duque de Béjar también se apropió comunales en sus estados. Ch. JAGO, «La 'crisis de la aristocracia' en la Castilla del s. XVIL, en Poder y sociedad en la España de los Austriar, Barcelona, 1982, págs. 272-273. Es una prueba más de que las prácticas de los señores iban a menudo más allá de lo permitido legalmente.

Hispania, LVIII/3, núm. 200 (1998) 1045-1096 
tuyen por diversos medios su base solariega y no quedan —al menos muchos de ellos-como perdedores durante el proceso de evolución del feudalismo al capitalismo.

Para evaluar el beneficio económico de los titulares de jurisdicciones debemos tener en cuenta, como dijimos, todas las rentas que perciben y no solo las derivadas de la jurisdicción. Aunque hay mucha variedad debemos destacar los monasterios como aquellos titulares con mayor base solariega en sus señorios ${ }^{40}$. En cuanto a las mitras, la situación es desigual: poco patrimonio rústico del obispo de Avila y Osma en sus señoríos y más importante el de los obispos de Salamanca y Zamora. El obispo de Osma recibe en 1574 — según la información mandada por el contador episcopal a S.M.-- unos 485 ducados ${ }^{41}$, cifra en la que no se diferencian las rentas derivadas de la jurisdicción de las temporales; proceden sobre todo de derechos devaluados sobre la tierra - como es el caso de la martiniega que percibe en casi todos sus lugares- y de censos derivados de una cesión perpetua de la tierra a sus vasalios. Por su parte la mitra salmantina percibe unos 1.043 ducados del patrimonio rústico de sus señorios, que tiene cedido generalmente en arrendamientos a corto plazo a sus vasallos ${ }^{42}$. En cuanto al obispo de Zamora también posee muchas propiedades cedidas en arrendamientos cortos. Respecto a la mitra segoviana percibe unos 1.184 ducados de bienes llevados por los vecinos de sus señoríos bien en censo perpetuo, bien en arrendamientos a corto plazo ${ }^{43}$. Deben tenerse presente estas rentas episcopales a la hora de estimar el beneficio económico que reportan los señorios a sus titulares; si sumamos las rentas de la tierra a las percibidas por vía jurisdiccional la mitra salmantina percibe un total de 1.565 ducados y la segoviana 1.338 ducados.

Aceptando como cierta la estimación de rentas globales de las mitras para 1577 que figura en el archivo secreto vaticano ${ }^{44}$ podemos decir que las rentas procedentes de sus señoríos suponen para el obispo de Osma un $2,2 \%$ del total, para el de Segovia un 5,6 y para el de Salamanca un 6,5\%. Pero debemos tener

40 Puede verse más información a este respecto en đLos señonios monásticos de Castilla $y$ León en el siglo XVI", M. ${ }^{a}$ A. FAYA DíAZ, art. cit.

41 Percibe un total de 325 fanegas de trigo, 325 de cebada, 48 de centeno y $112.000 \mathrm{mrs}$, de los que 69.000 proceden de las cuatro fortalezas que tiene (Osma, Ucero, Cabrejas y Gomara).

42 Recibe 512 fanegas de trigo, 344 fanegas de cebada, 15 carretadas de paja, 15 gallinas y $143.425 \mathrm{mrs}$

43 Le pertenecen 348 fanegas de trigo, 263,5 fanegas de cebada, $95.666 \mathrm{mrs}$ y $208.050 \mathrm{mrs}$ de juro sobre las alcabalas de cuatro de las villas del obispo. Como puede verse, contratos enfiteúticos y arrendamientos a corto plazo coexisten en Castilla-León como formas de llevar la tierra. Se puede decir que los atrendamientos son ya muy frecuentes, aunque formas enfiteúticas se dan a menudo en Burgos, Soria y la Rioja; son frecuentes en las tierras dependientes del obispo de Osma, así como de la mayoría de los monasterios de esta zona norte de Castilla la Vieja.

44 Según el citado documento las rentas del obispo de Osma subirian a 22.000 ducados y las de los de Salamanca y Segovia a 24.000 ducados cada uno de ellos. B. ESCANDELL. BONET', "Las rentas episcopales en el siglo XVI, Anuario de Historia Económica y Social, 3, 1970, pág. 76. 
en cuenta que las mitras perciben frecuentemente los diezmos; no tenemos mucha información sobre esta cuestión en nuestros documentos, ya que las averiguaciones se suelen limitar a las urentas jurisdiccionales» y a las "rentas temporales" y no a las derivadas del gobierno espiritual.

Nos faltan los datos sobre las mitras salvo la de Zamora, de la que conocemos las cantidades globales que percibía en sus lugares jurisdiccionales, en las que se incluían los diezmos. Todas sus rentas las tenía arrendadas, recibiendo de sus arrendatarios un total de 9.662 ducados anuales; si tenemos en cuenta que en 1577 podría recibir esta mitra unos 20.000 ducados anuales, las percepciones en sus señoríos supondrían el $48 \%$ del total. Haría falta conocer los diezmos que percibían el resto de los obispos castellano-leoneses para ver hasta qué punto se puede generalizar la situación observada en Zamora. Está claro que a la mitra zamorana le es muy útil la posesión de la jurisdicción ya que le permite cobrar casi la mitad de sus rentas de modo tranquilo y seguro ${ }^{45}$.

Las quejas que muchos monasterios aducen ante el Consejo de Hacienda para que no se les quiten sus señoríos aluden siempre al perjuicio económico que ello les traería; a muchos se les reconocerá este daño y no se les venderán sus lugares. El presidente general de la orden de San Bernardo alude a motivaciones clatamente económicas y dice que si se les quitase la jurisdicción sería causa de que los monasterios «se deshiziesen y despoblasens y que como muchos de sus vasallos uson solariegos y feudatarios... y como la rrenta de dichos lugares es mucha mas que el vasallaje es de mucho ynconveniente para recompesallaw. También otras instituciones alegan daño económico; así la abadía de San Isidro de León, a la que se unen los procuradores en Cortes de la misma ciudad, piden ante el Consejo de Hacienda que no se vendan los lugares de Espinosa, Pinos y San Millano, entre otras razones porque

"quitandoseles la jur"on no podrian cobrar sus rentas a lo menos sin mucha costa y travajo ... y el daño que dicha rreal casa reciviria es excesivo y grande... ya que tienen $<e n /$ dhos /tres lugares > la mayor y mejor parte de sus rrentas》

El Deán y Cabildo de la catedral de León alega «el mucho daño y perjuizio« que les traería la venta de vasallos y solicita que, al menos, se les dejen dos lugares (Villanueva y Cillanueva) dado que tienen en ellos gran parte de su hacienda. El obispo de León dice, por su parte:

"Los eclesiasticos estamos muy cargados.. la tierra es muy pobre y adonde acuden mucbos estranjeros mayormente asturianos a que no podemos dejar de acudir y que si sobre todas estas cosas nuevamente se nos disminuye la bacienda no podremos cumplir con nuestras obligaciones ni remediar a las muchas necesidades extremas que cada dia ocurrens 46.

45 En Zamora no sólo el obispo sino también el resto de titulares eclesiásticos perciben diezmos en sus señorios y a menudo llevan la totalidad de ellos. J.A. Alvarez Vázquez, Las diezmos en Zamora (1500-1840), Zamora, 1984, págs. 161-163.

46 A.G.S., Cons. y J. de Hac., lg. 128, 3; lg. 211, 6; $\lg .194,2$ y lg. 135, 2, respectivamente.

Hitpania. LVIII/3, núm. 200 (1998) 1045-10\% 
De cualquier modo, la posesión de la jurisdicción no solamente trae beneficios económicos directos o indirectos a sus titulares; también les da, sobre todo a los obispos, prestigio y autoridad, tal y como reconocen con frecuencia ante la Administración cuando en 1574 se les notifica la bula del Papa que legaliza las ventas. El obispo de Salamanca argumenta a S.M. que

"Los lugares de esta dignidad rentan muy poco al prelado pero con ellos tiene mucha autboridad con que en alguna manera se suple la tentidad de las rentas episcopales que segun la grandera de la ciudad y diocesis y la multitud de las necesidades de la gente no llegan con mucho a lo que seria menester para socorrerles ni aun para authorizar al obispo... Suplico a V.M. bumildemente ... se sirva de mandar suspender la venta de las jurisdictiones temporales por el tiempo que yo las paseyese... ${ }^{47}$.

Tanto la postura de los hombres de señorio como la resistencia activa por parte de los titulares eclesiásticos a la desmembración y venta de sus jurisdicciones a pesar de que no estaba en entredicho la propiedad de la tierra, nos hace llegar a la conclusión de que la jurisdicción tiene más importancia de la que se suele admitir, que es considerada perjudicial y vejatoria por los vasallos y beneficiosa su posesión por los señores, siendo ambas partes plenamente conscientes de ello ${ }^{48}$.

Para terminar esta cuestión, evaluando la situación de los hombres de señorío desde una perspectiva global podríamos comparar la situación del campesino castellano con la de otros europeos, especialmente con los de otras regiones españolas, lo cual frecuentemente no se hace. Así, se suele aducir con frecuencia la benignidad del régimen señorial castellano con respecto, por ejemplo, al valenciano; se argumenta que las cargas que satisface el vasallo valenciano son más pesadas debido a la importancia que allí tienen los monopolios señoriales y la partición de frutos ${ }^{49}$. Efectivamente ello es así, pero desde

47 A.G.S., Cons. y J. de Hac., lg, 135, fol. 2.

48 Algunas instituciones eclesiásticas piden a S.M. que en caso de desmembración de sus lugares permita que se compren los concejos, expresando el mismo temor que los vecinos ante la perpectiva de que pase a seriorío particular; así el abad de Valladolid pide que sea de este modo en el caso de que se le venda la villa de Olivares (A.G.S., Exp. Hac., 338, fol. 3). Otras veces solicitan únicamente poder tener un juez para seguir cobrando sus tentas.

49 Son urgentes estudios comparativos que apenas existen, aunque podemos citar en este sentido a SAAVEDRA, P., «Señorios y comunidades campesinas en la España del Antiguo Régimenn, en Sarasa Sánchez, E. y Serrano Martín, e. (Eds.), Señorio y Feudalismo en la Península Ibérica, vol. I, Zaragoza, 1993, pags. 427-474. Pero es necesaria una metodología homogénea para llevarlos a cabo así como más investigaciones regionales. En Castilla y Andalucía el objeto de atención fue la propiedad de la tierra y su explatación y hubo una despreocupación -que sigue existiendo- por las estructuras señoriales, a las que no se da suficiente importancia. La producción historiográfica sobre el señorio valenciano es más abundante ya que en esta región se ha configurado como tema específico. Asi, podriamos citar los trabajos de M. Peset, M. Ardit, E. Císcar Pallarés, A. Gil Olcina, I. Moránt, A. Mora y P. Ruiz Torres. La interpretación del señotio valenciano ha evolucionado, descartándose hoy la idea de dureza como causa de la 
un punto de vista global hay que tener en cuenta que el vasallo valenciano satisface la mayor parte de sus pagos por vía jurisdiccional dada la mayor base solariega de los señoríos de esta regiôn, mientras que el castellano paga al señor derechos jurisdiccionales de menor cuantía, pero también debe la renta por las tierras que lleva de otros propietarios y ello supone cantidades importantes. Además hay que tener presente que en el País Valenciano el sistema de partición de frutos impide la devaluación de los derechos a pagar; no obstante, los contratos generalmente enfiteúticos dan más estabilidad al campesino y suponen en total cantidades menores que las que pagan muchos campesinos castellanos, los cuales, además de los derechos del señor, deben satisfacer - a veces al propio titular de la jurisdicción-cantidades importantes y actualizadas continuamente por las tierras que llevan en arrendamiento y de las que se les puede desahuciar. En este estudio comparativo habria que tener presente también la diferente carga fiscal a que está sometido el campesino castellano y el valenciano. Analizando la situación del campesinado desde un punto de vista global N. Salomon considera que en Castilla la Nueva más del $50 \%$ de la cosecha se destinaba, por diversos títulos, a enriquecer a las clases no campesinas ${ }^{50}$.

En cuanto a la situación socioeconómica de los vasallos debemos decir que no es homogénea, al igual que sucede en los lugares de realengo; hemos constatado la uniforme pobreza de los campesinos en los lugares solariegos así como una estratificación campesina en otros lugares, especialmente en las villas de mayor población, pero nuestra documentación no permite muchas matizaciones. Yun Casalilla considera, refiriéndose a la tierra de Campos, que la propiedad campesina fue importante durante la mayor parte de la centuria, predominando los pequeños agricultores que complementan su economía con el uso de baldios y comunales; asimismo destaca que en la primera mitad del siglo la presión fiscal y señorial es pequeña y que la renta de la tierra no es excesivamente alta --sobre un quinto de la cosecha - ${ }^{51}$. Pero esta estabilidad del

contestación antiseñorial, tal como lo planteaban Ardit y Ciscar Pallarés; P. RuIz Torres considera últimamente que hay una relativa debilidad del componente territorial mientras subraya la importancia del poder jurisdiccional y las rentas derivadas del mismo, especialmente los monopolios ("Los señoríos valencianos en la crisis del Antiguo Régimen: una revisión hístoriográficas, Estudis d'Història del Pais Valencià, 5, Valencia, 1984, págs. 23-79).

50 N. SALOMON, La vida rural castellana en tiempos de Felipo II, op. cit., pág. 257.

51 Sobre la transición al capitalismo en Castilla, Economia y sociedad en tierra de Campos (15001830), op. cit. Lo mismo opira F. BRUMONT (Campo y campesinos de Cartilla la Vigja en tiempos de Felipe II, Madrid, 1984) y D.E. VASSBERG (Tierra y saciedad en Cartilla, Barcelona, 1986). Brumont considera, a propósito de la Bureba, que aunque la propiedad de los monasterios era muy importante el $50 \%$ de las tierras estaban en manos de los campesinos. Vassberg, por su parte, dice que la quinta parte de las tierras de Castilla era propiedad de los campesinos, aunque el reparto de la propiedad es muy desigual según las zonas; reconoce además la pétdida de peso de la enfiteusis - tan favorable para los campesinos- desde mediados del siglo. A. Garcia Sanz también destaca para Segovia el nuevo tipo de racionalidad económica que se impone en esté siglo en el que tienden a aumentar los arrendamientos cortos, mientras pierden importancia los censos enfiteúticos tan frecuentes anteriormente. A. Garcí SANZ, Desarrollo y crisis del Antiguo Régimen en Castilla la Vieja, Madrid, 1986. En

Hispania, LVIII/3, núm. 200 (1998) 1045-1096 
campesino castellano es amenazada a lo largo del siglo al aumentar la presión fiscal, al disminuir los contratos a largo plazo y generalizarse los contratos revisables y al vender la Corona baldíos de los pueblos ${ }^{52}$. Para muchos lugares de señorío eclesiástico que compran la jurisdicción cuando la pone en venta la Corona será éste un esfuerzo suplementatio que traetá la ruina a muchos campesinos, como veremos después.

Con el fin de allegar fondos para su política exterior, Carlos V y Felipe II recurrirán en momentos especialmente delicados de la hacienda real a la venta de señoríos de la Iglesia. Vamos, pues, a referimos al proceso legal seguido, que los reyes hacen partir de una licencia papal. Dado que las bulas de Julio III y de Gregorio XIII permitían desmembrar jurisdicciones de la Iglesia por valor de 500.000 y 40.000 ducados respectivamente, la Corona inició los trámites de desvinculación y venta de lugares eclesiásticos: averiguación general de señoríos de la Iglesia e información a todos aqueilos que quisiesen comprar (vecinos afectados, nobleza, oligarquías urbanas), acciones que fueron encomendadas a los alcaldes mayores del Adelantamiento, corregidores o jueces de comisión especialmente mandados al efecto.

Los interesados en comprar un lugar debían ir al Consejo de Hacienda a solicitar la compra; para evaluar el precio de venta la Administración procedía a la averiguación particular del lugar pedido encomendándola a un juez de comisión especialmente designado; éste había de determinar el número de vecinos y el desglose pormenorizado de los derechos jurisdiccionales que anualmente percibia su titular, elementos en base a los cuales se determinaba el precio de compra ${ }^{53}$. El Consejo de Hacienda hacía la cuenta y después se podían iniciar los trámites de compra propiamente dicha para lo cual era pre-

la misma linea, GARCíA DE CORTAZAR opina que mientras el campesino de León y Castilla la Vieja se había recuperado económicamente en el s. XV, a partir de mediados del s. XVI empeora su situación debido a que tienden a imponerse contratos a más corto plazo; La sociedad rural en la España medieval, Madrid, 1988.

52 Fueron especialmente importantes las ventas en las provincias de Zamora y Valladolid. D.E. VASSBERG, La venta de tierras baldias. El comunitarismo agrario de Castilla durante el siglo XVI, Madrid, 1983. A. GARCíA SANZ confirma a través de sus investigaciones la disminución del número de pequeños propietarios y la crisis de las comunidades aldeanas en el interior peninsular a partir de las últimas décadas del s. XVI, en DíAz, R. (ed.), La España del sigla XVIII, Barcelona, 1985, pgs. 650-51.

53 En las ventas de tiempos del Emperador se valoraron las rentas jurisdiccionales en $43.000 \mathrm{mrs}$ el millar y el precio por vecino era variable, dependiendo de que fueran «buenos» 0 "imalos» vasallos; estuvo entre los ocho mil mis por vecino en que se evaluaron los de Pesadas hasta los veinte mil mrs que valió cada vasallo de Población de Cerrato. En las ventas derivadas de la bula de Gregorio XIII se estipuló a $42.500 \mathrm{mrs}$ el millar de rentas jurisdiccionales y a $16.000 \mathrm{mrs}$ cada vasallo, aunque en el caso de que el lugar no llegara a 100 vecinos quedaba a criterio de la Administración decidir si se vendía por vecinos o por término, fijándose el precio de éste en 1.500.000 mrs por legua cuadrada. En este último cásó se decidía vender por el criterio del que resultare una cantidad mayor, lo cual significaba que los lugares de menor densidad de población y más pobres eran a menudo los que resultaban más caros. 
ceptivo indemnizar al antiguo titular y desmembrar el lugar de él, así como incorporarlo a la Corona.

Se puede decir que se desmembran y venden las jurisdicciones que tienen comprador, aunque no todos los lugares solicitados van a ser apartados de sus titulares. La demanda de señoríos de la Iglesia fue importante en las dos etapas en que se emprendió la venta de jurisdicciones eclesiásticas; por tanto, numerosos lugares fueron averiguados y algunos desmembrados e incluso indemnizados. Pero no todos fueron vendidos; de un total de 650 enclaves señoriales dependientes de instituciones eclesiásticas que hemos podido constatar en Castilla-León sabemos que se vendieron 127, lo que supone aproximadamente la quinta parte de ese total. No obstante, si tenemos en cuenta el número de vasallos vendidos el porcentaje se dobla: de los 40.839 vecinos dependientes de la Iglesia se vendieron 15.805 ; o sea, aproximadamente un $40 \%$. Esta diferencia notoria según el distinto criterio utilizado se explica por el hecho de que los lugares dependientes de mitras, que generalmente eran núcleos de población más importantes, fueron más afectados por las ventas que los lugares de monasterios.

CUADRO B. Lugares eclesiásticos vendidos en el siglo XVI y estatuto juridico posterior

\begin{tabular}{|l|c|c|c|c|c|c|c|c||}
\hline \multirow{2}{*}{ Provincias } & \multirow{2}{*}{$\begin{array}{c}\text { Lugares/ } \\
\text { Vasallos }\end{array}$} & \multicolumn{2}{|c|}{$\begin{array}{c}\text { Estatuto juridico en el S. XV1 } \\
\text { (lugares/vecindad) }\end{array}$} & \multicolumn{3}{|c|}{ Estatuto juridico en el s. XVIII } \\
\cline { 3 - 10 } (lugares)
\end{tabular}

Hípania, LVIII/3, núm. 200 (1998) 1045-1096 
Estas cifras globales no nos deben ocultar tampoco las diferencias geográficas en cuanto a la efectividad de las desmembraciones y ventas, cuyos datos concretos se resumen en el cuadro B. De mayor a menor incidencia tenemos: el obispado de Segovia con un $72 \%$ de vasallos desvinculados; le sigue Zamora con un $63 \%$, Salamanca/Ciudad Rodrigo con un $61 \%$, Avila con un $47 \%$, Palencia con un $41 \%$, Osma con un 34\%, León/Astorga con un $31,5 \%$ y Burgos/Calahorra con un $23 \%$. La menor incidencia de las ventas en las dos últimas zonas citadas está relacionada sin duda con el hecho de que es la región norte de Castilla-León la que tiene el más alto porcentaje de vasallos monásticos, que como dijimos, fueron menos afectados por las desvinculaciones; también hay que tener en cuenta que hubo menos demanda de jurisdicciones y, por tanto, compradores.

Debemos tener en cuenta la distinta importancia de las ventas en las dos épocas en que se llevaron a cabo. En tiempos del Emperador solo nos consta que se vendieran finalmente en Castilla-León 12 lugares que suman unos 1.075 vasallos (tal como vemos en el cuadro II, anexo a este trabajo), lo que supone escasamente un $7 \%$ del total de vasallos vendidos en el siglo XVI. La bula de Julio III solo permitía vender señorios monásticos, mientras que la de Gregorio XIII, que fue más efectiva, afectaba a todo tipo de instituciones eclesiásticas, excepto a las Ordenes Militares. También en esta fase fueron salvaguardados de las ventas muchos señoríos de monasterios: en virtud de la última bula se vendieron 1.972 vasallos monásticos ${ }^{54}$ que sumados a los anteriores dan un total de 3.046, lo que supone únicamente el 19\% del total de los vasallos eclesiásticos vendidos.

Para explicar la relativa importancia de las secularizaciones efectuadas, especialmente las escasas ventas de lugares de monasterios debemos referirnos a la oposición de la Iglesia. Todo el estamento eclesiástico se opondrá a este expediente arbitrado por la Corona. Tras la concesión de la bula de Julio III una junta de teólogos reunida en 1553 critica las desvinculaciones considerando estos actos poco acordes con el espíritu cristiano y apela a la conciencia del rey; alude a la dudosa validez jurídica de las acciones emprendidas y las considera un atentado contra el poder económico y el prestigio social de la Iglesia. En el mismo sentido se manifiestan el dominico fray Hernando del Castillo y Sancho Busto de Villegas, gobernador del arzobispado de Toledo, en cartas dirigidas a Felipe II en 1574, año de la concesión de la bula por Gregotio XIII. Igualmente se manifiesta el presidente general de la orden de San Bernardo, el cual se ofrece a pagar una cantidad para que cesen las ventas de jurisdicciones de dicha orden «teniendo consideracion la dicba orden a las mucbas y grandes necesidades que

54 Se vendieron 1299,5 vasallos del monasterio de Nájera (los lugares de Leza, Nestares, Ribafrecha, Santoña, Santurdejo, Sojuela, Torrecilla de los Cameros y Trevijano), 150 del monasterio de San Prudencio (Lagunilla), 139 del de Espinaredo (Tombrio de Abajo, San Juan de la Mata),113 del de Sahagún (Cofinal,Villanueva de San Mancio, Canalejas y Calaveras de Abajo), 87 de San Pedro de Montes (Villanueva de Valdueza) y 49 del de Benevivere (Argovejo).

Haspania, LVIII/3, núm. 200 (1998) 1045-1096 
vuestra magestad tiene de presente y a las justas causas de donde proceden ${ }^{55}$. La misma oferta hizo la orden de San Benito aunque no nos consta que la hubieran llevado a la práctica ${ }^{56}$. Sí sabemos que algunos monasterios pagaron a nivel particular una cantidad para poder conservar sus jurisdicciones ${ }^{57}$.

Muchos monasterios aducen de modo unánime el perjuicio económico que la pérdida de la jurisdicción les acarrearía y presentan contradicciones a la venta de sus lugares en las que argumentan que tendrían dificultades para cobrar las rentas que percibían, así como que no realizarían las prestaciones de trabajo a que muchos de ellos estaban obligados. El Consejo de Hacienda tendrá en cuenta en muchos casos estos argumentos y en 1554 decide que no se vendan los lugares que sean solariegos, aquellos donde estuviera sito el monasterio o que sean granjas de recreo de los monjes así como los que fuesen de jurisdicción compartida con otro tituilar ${ }^{58}$. La misma oposición de los monasterios tiene lugar en el momento de aplicar la bula de Gregorio XIII; las protestas de los monasterios influyen, sin duda, en la menor incidencia de la desvinculación de sus jurisdicciones.

La actitud de los obispos, tal como se desprende de las cartas que envían a Felipe II tras notificárseles las acciones que se iban a emprender, es más comprensiva con los objetivos políticos a que iban destinadas. Aunque aducen el daño económico y sobre todo la merma de autoridad que les traería la pérdida de la jurisdicción, no obstante, expresan también acatamiento, tal como podemos ver en la carta del obispo de Osma:

«Tengo por fierto que como tan christianisimo ningun bombre ay en el mundo que tanta quenta tenga con su conciencia como V.M. de creer es que V.M. Lo tiene bien visto y pesado y ansi $V . M$. Lo mandara proveer como mas conviene al servicio de nuestro señory de V.M. $y$ bonrra de las yglesiass ${ }^{59}$.

La oposición de la Iglesia ayuda a explicar que la desvinculación de señotíos de la Iglesia no llegara a ser un fenómeno general, así como también la tardanza

55 A.G.S., Cons. y J.de Hac., lg. 128, fol. 3.

56 Información de Juana de Austria a Carlos V el 19 de enero de 1555. Fernóndez AL varez, V.M., Corpus documental de Carlos V, t. IV, pág. 175.

57 Nos consta que el monasterio de Sahagún se concertó con la Corona el 23 de julio de 1582 en pagar 7.000 ducados para que no se desmembrasen los lugares de Santervás, Villafrades y Galleguillos; aduce para que no se vendan que upor los años baber sido esteriles" y otras razones debe el monasterio 24.000 ducados, mientras por otro lado debe sustentar 65 religiosos y muchos criados, un hospital para peregrinos y enfermos y otras obras de caridad. A.G.S., Merc. y Priv., lg. 290, fol. 9. Igualmente en 1590 pagó 900 ducados para recuperar el lugar de Nogal que ya había sido vendido. A.G.S., D.G.T., lg. 284, fol. 40 . Tambièn los monasterios de Carracedo y San Clodio ofrecieron a S.M. 12.000 ducados para que no se desmembrasen sus lugares. A.G.S., Merc. y Priv, lg. 274.

58 Relación de lugares a quienes se ha respondido que no se habia de vender la jurisdicción por estar los monastetios sitos en los mismos lugates. A.G.S., Metc. y Priv., lg. 251, fol. 1. Documento recogido por A.M. Guilarte, El régimen señorial en el siglo XV T, Valladolid, 1988, pás. 301-305.

59 A.G.S., Cons. y Juntas de Hac., lg. 135, fol. 2.

Hìqunia, LVIII/3, núm. 200 (1998) 1045-1096 
en su aplicación. Tras la bula de 1551 no se realizaron ventas de lugares de monasterios hasta $1555^{\circ 0}$, año en que se desmembraron la mayoría de los lugares que sabemos vendidos. Pero también sabemos que se hizo una venta en 1559 y otra en 1565 a pesar de que el nuevo papa Paulo IV expidió una bula por la que anulaba todas las enajenaciones efectuadas al amparo de la dada por Julio III. El breve de Gregorio XIII fue llevado a la práctica con más decisión, pero necesitó ser ratificado el 14 de marzo de 1579; entre 1574 y 1578 se desmembraron y vendieron muy pocos lugares ${ }^{6}$.

Por otro lado, Felipe II, como demuestra su testamento, se arrepintirá de las desmembraciones eclesiásticas levadas a cabo y pretenderá que se restituyan a la Iglesia los señoríos que ya estaban vendidos desde hacía tiempo. Aunque Felipe III inició los trámites para cumplir la voluntad paterna la restitución ya no era posible. Los escrúpulos reales ayudan a explicar también porqué no se agotaron los 40,000 ducados que permitía la bula papal.

La venta de vasallos eclesiásticos trata de paliar los agobios financieros derivados de la política imperial de los Austria. R. Carande nos informa de cómo el Emperador tenía gran cantidad de obligaciones de pago desde 1546; en sus últimos años reclama dinero para cumplir con los banqueros que le habían socorrido y para proseguir sus campañas contra los protestantes y contra Enrique II; estaban también las campañas de Italia. En los años setenta las desvinculaciones fueron una solución arbitrada para pagar a los acreedores de la Corona - con quienes tenía suscritos asientos- - tras la suspensión de pagos de 1575. En 1578 se acordó con los del «medio generab» y con «los hombres de Flandes» pagarles la deuda, dos tercios en juros y un tercio en vasallos de la Iglesia. De ahí el protagonismo que dichos hombres de negocios, sus agentes o apoderados tendrán en las ventas. Algunos van a los lugares y buscan compradores con los que fijan el precio y condiciones de pago y posteriormente piden a la Administración se inicie la averiguación de los lugares solicitados y el resto de los trámites. A veces, si aún no hay comprador, llegan a tomar posesión y disponen del lugar hasta que lo encuentran. Ademas, en muchas ocasiones cobran directamente de los compradores la cantidad estipulada con ellos, que con frecuencia es menor que la fijada por la Corona ${ }^{62}$; la cuenta de la Administración servirá pues, únicamente para descontar de la deuda que tiene con dicho acreedor.

60 El 2 de septiembre de 1553 Felipe informa al Emperador de lo resuelto por los teólogos sobre el tema, a lo que éste responde que «tisto al parecer de los theologos que mandaste juntar par ahora no se deve tractar dellàn. FERNÁNDEZ Alvarez, V.M., Corpus documental de Carlos $V$, t. III, págs. 606 y 663 .

61 Las ventas en Castilla-León tuvieron lugar entre 1574 y 1592. Las fechas de los juros de indemnización concedidos a las instituciones eclesiásticas están comprendidas entre 26-11574 (villas de Hinojosa y Mejorada) y 17-12-1592 (villa de Santuy).

62 Así, Nicolás de Grimaldi, principe de Salerno, hace asiento con el comprador de Veganzones por el que éste debe pagar a $9.500 \mathrm{mrs}$ por vecino; Pedro de ísunza vende San Bartolomé de Corneja y El Guijo a 10.666 mrs por vasallo y Alonso de Camino Puerto de Santona a 9.500, mientras la Administración les carga la venta a $16.000 \mathrm{mrs}$ por vecino.

Hitpania, LVII1/3, п11เก. 200 (1998) 1045-1096 
La nómina de hombres de negocios que pidieron lugares y a quienes se cargaron las sumas resultantes de su venta es larga e incluye tanto hombres de negocios genoveses como castellanos: Baltasar Catano, Bernabé Centurión, Nicolás de Grimaldi, Vicencio Gentil, Esteban y Baltasar Lomelin, Agustín Spínola, Esteban Grillo, Juan María Corbari, Diego de Chavarri, Diego Pardo, Juan Curiel de la Torre, Alonso López Gallo, Alonso Díaz de Aguilar, Pedro de Isunza, Juan Fernández de Espinosa, Hernando de Frías, Alonso de Camino, Marcos Núñez Pérez y Hernando de Sevilla, entre otros.

El convenio acordado con los acreedores supone, en definitiva, la consolidación de deudas a corto plazo en deudas a largo plazo, quedando gravada la Corona con muchos juros. Lo mismo sucede con la venta de vasallos eclesiásticos, ya que la indemnización a la Iglesia se instrumentará también en juros. Las cantidades anuales a recibir por las instituciones afectadas, que serán situadas de modo perpetuo sobre la recaudación de ingresos de la Corona, corresponden únicamente a la renta que percibían por vía jurisdiccional en los lugares desmembrados; sólo se indemnizan los derechos jurisdiccionales, los cuales se estiman a través de las averiguaciones particulares de cada lugar, hallando el promedio de los derechos jurisdiccionales de los cinco años últimos.

CUADRO C. IMPORTE DE LAS VENTAS EN CASTILLA-LEÓN

\begin{tabular}{|l|c|c|c|}
\hline \multicolumn{1}{|c|}{ Obispado } & $\begin{array}{c}\text { Recuento de vecinos } \\
\text { para la venta }\end{array}$ & $\begin{array}{c}\text { Derechos jurisdi- } \\
\text { cionales indemni- } \\
\text { zados (mrs) }\end{array}$ & $\begin{array}{c}\text { Precio de venta } \\
\text { (mrs) }\end{array}$ \\
\hline Ávila & 856,5 & $20.646,5$ & 14.581 .506 \\
\hline Burgos y Calahorra & $1.908,5$ & 68.538 & 32.948 .703 \\
\hline León y Astorga & $3.601,5$ & 131.834 & $70.087 .104,5$ \\
\hline Osma & 892 & $104.337,5$ & $22.265 .485,5$ \\
\hline Palencia & 1.769 & 75.176 & 32.618 .325 \\
\hline Salamanca y C. Rodrigo & 3.120 & $177.551,5$ & 54.427 .772 \\
\hline Segovia & $1.382,5$ & 29.713 & $23.120 .776,5$ \\
\hline Zamora & 2.765 & $161.724,5$ & 55.093 .951 \\
\hline Totales & 16.295 & 769.521 & $305.143 .623,5$ \\
\hline
\end{tabular}

* Cuando el lugar no llegaba a 100 vecinos generalmente se vendia por término en vez de por vecinos.

Mientras que la Iglesia resultó perjudicada por la venta de sus jurisdicciones, ya que generalmente percibía cantidades pequeñas por vía jurisdiccional, la operación resultó mucho más rentable para la Corona al vender las rentas jurisdiccionales y los vasallos ${ }^{63}$. Recibe por los lugares castellano-leoneses un total vasallo.

63 Se tasó cada millar de rentas jurisdiccionates a $42.500 \mathrm{mrs}$ y cada vecino a $16.000 \mathrm{mrs}$ por

Hippanid, LVII1/3, núm. 200 (1998) 1045-1096 
de 813.716 ducados ${ }^{64}$, mientras que la indemnización a las instituciones eclesiásticas sólo es de 2.052 ducados; esto significa que la Administración allegó por la venta de señoríos de la Iglesia un dinero por el que iba a pagar únicamente un $0,25 \%$. El desglose por obispados de estos totales podemos verlo en el cuadro $\mathrm{C}$.

No obstante, la Corona podía haber obtenido mucho más beneficio de la bula de Gregorio XIII si hubiese vendido más lugares. De los 40.000 ducados que ésta autorizaba utilizó poco más de 2.000 ducados en Castilla-León. Podía haber realizado más ventas en el conjunto de la corona de Castilla pues no agotó la cantidad que le estaba permitida. Mayores precisiones podremos hacer cuando evaluemos el resto los obispados; el caso del de Oviedo ya to hemos estudiado: 557,5 ducados indemnizados a las instituciones eclesiásticas. A través de los juros que se conservan en la Contaduría de Mercedes podemos acercarnos de manera aproximada al total de rentas jurisdiccionales desmembradas a la Iglesia en la corona de Castilla en los años setenta y ochenta: suman unos 8.772 ducados. Este documento puede que no incluya todos los juros de lugares vendidos y que hubiese más ventas, mientras que están otros juros que finalmente fueron rasgados al decidirse finalmente que algunos señorios no se desmembraran de sus titulares.

Pero sin duda no se agotaron ni mucho menos los 40.000 ducados permitidos por el Papa. En un informe del Consejo de Hacienda hecho en 1588 se dice que las rentas jurisdiccionales tomadas no llegaban a 15.000 ducados, por lo que todavía podian venderse los 25.000 restantes; recomienda que se haga así ya que ello supondría sacar una importante cantidad de dinero que saldría a muy bajo interés aunque se pagara la indemnización a la Iglesia ${ }^{65}$. Este informe no está hecho con rigor y es claramente exagerado tanto en el monto que suponía que podía conseguir la Corona (que estima en 16.062 .500 ducados) como en las rentas jurisdiccionales realmente desmembradas. Según Dominguez Ortiz, en 1600 el presidente de la Cámara de Castilla considera que sólo se habían desmembrado en total 9.424 ducados ${ }^{66}$, lo cual nos parece que se acerca más a la realidad.

La demanda de señoríos de la Iglesia fue importante y hubo muchos compradores incluso para lugares que finalmente la Administración decidió no vender. En el privilegio de venta que se les concedia estaba incluida la jurisdicción civil y criminal, alta y baja, mero mixto imperio; las atribuciones de los señores y derechos jurisdiccionales a percibir debían seguir siendo los mismos de que gozaba el antiguo titular, sin introducir cambios. En el caso de redención de los vecinos, el lugar quedaba incorporado a la Corona y a cambio del

\footnotetext{
64 Está incluído en esta cuenta el importe de las ventas de Mejorada y Pozuelo, lugares del obispo de Segovia localizados en Madrid.

${ }_{55}$ Nos consta que aun en los últimos años del reinado de Felipe II se hicieron trámites para vender señoríos eclesiásticos sobre todo en Galicia.

66 "Ventas y exenciones de lugares durante el reinado de Felipe $I V$ ", en Instituciones y sociedad en la España de los Austrias, op. cit,, pág. 57.
}

Hi.pania, LVIII/3, núm. 200 (1998) 1045-1096 
servicio ofrecido a ésta recibía, además del nombre de villa, una amplia autonomía: los oficios serían elegidos por el concejo y únicamente sus jueces tendrían la primera instancia así como las apelaciones en lo civil hasta 10.000 mrs. Solamente las apelaciones de los casos criminales, así como los civiles de $10.000 \mathrm{mrs}$ arriba irían a las justicias y tribunales reales. Se le garantizaba además que nunca podría ser vendido ni aumentados sus oficios.

Entre los compradores figuran algunos eclesiásticos y miembros de la nobleza titulada, pero sobre todo personas pertenecientes a la alta burocracia y a las oligarquías ciudadanas. Sin duda, uno de los móviles que impulsaba a estos grupos era el prestigio; ser señor de vasallos facilitaba a su poseedor el ascenso en la escala social, era un paso previo al ingreso en la nobleza titulada, situación que va a ser frecuente en el siglo XVIII en los titulares de antiguos señoríos eclesiásticos. Pero la búsqueda de honores $-\mathrm{y}$ por tanto de poder - no está reñida con los móviles económicos. Aunque los derechos jurisdiccionales que van a percibir no son cantidades significativas, en algunos casos al menos la búsqueda de rentabilidad económica al dinero empleado figura también entre sus intenciones. El poder que adquieren abre vías diversas en la búsqueda de beneficio económico y esa será la actitud de algunos señores desde el mismo momento de la toma de posesión de los lugares comprados ${ }^{67}$.

De cualquier modo, los más interesados en la compra son los propios pueblos de señorío. De los 15.575 vasallos vendidos, 10.956 se compraton a sí mismos y sólo 4.619 pasaron a señorio particular (70\% y $30 \%$ respectivamente) ${ }^{6}$. Con base en estos datos podemos decir que la redención de los pueblos de señorio es un fenómeno bastante general y demuestra los verdaderos sentimientos de los pueblos hacia el régimen señorial. No son únicamente los vecinos más acomodados los interesados y, por tanto, protagonistas de la redención; los lugares solariegos, cuyos vecinos son pobres y de estatus igualitario, también solicitan -aunque en este caso sin conseguirlo- la redención ${ }^{69}$.

67 En el mismo sentido podemos ver los datos sobre intención de compra que aparecen en los cuadros III, anexos a este trabajo.

68 La cuenta está hecha en base a los datos que figuran en el cuadro $B$.

69 De cualquier modo, los vasallos que no tienen hacienda o tienen muy poca y que, por tanto, no pueden pagar su exención, es lógico que no quieran comprometerse en esta cuestión. Sabemos cómo a menudo pobres y huérfanos salen del lugar cuando el juez averiguador va a hacer el padrón, lo que puede indicat falta de compromiso con la redención, aunque también es cierto que los padrones que le entregan los pueblos ocultan a algunos vecinos-especialmente los más necesitados- con la finalidad de que suba menos la compra. En Zofraga, Fuentesaúco y San Martin de Castañar sabemos que los más pobres no querían redimirse, lo cual indica una postura realista puesto que para muchos vasallos la autocompra traerá el endeudamiento $\mathrm{y}$, posteriormente, la pérdida de sus propiedades y el abandono del lugar donde vivían. De estos hechos no debe concluirse que solamente los más ricos deseen liberarse del régimen señorial, como a veces se dice, deduciendo de ello incluso la benignidad del sistema. Muchos pueblos, tras unos meses, incluso años, de estar sometidos a un nuevo señor se quejan de sus vejaciones y malos tratamientos y piden al rey la redención fuera del plazo de los cuatro meses; y tenemos ejemplos de que el Consejo falló a su favor.

Hipaniu, LVIII/3, núm. 200 (1298) 1045-1096 
Por tanto, la actitud de los pueblos ante las ventas es clara; bien piden directamente la exención, bien se acogen al derecho de tanteo tras comprarles un particular. Tanto en la solicitud al Consejo de Hacienda como en el asiento que hacen posteriormente con la Administración expresan el temor a pasar nuevamente a señorío; les aterra pasar a depender de un señor y aprovechando las condiciones ventajosas de la Corona - pueden tantearse si van en un plazo de cuatro meses tras tomar posesión el nuevo titular- se redimen a pesar de sus pocas posibilidades económicas. A veces incluso van fuera del plazo alegando la coacción a que estaban sometidos por el comprador ${ }^{70}$.

El cambio de estatuto jurídico de los pueblos redimidos fue generalmente traumático para éstos por motivos diversos, cuya complejidad no podremos analizar aquí. Pasar a realengo significa, en primer lugar, cumplir con los censos pedidos al efecto. El rey les daba facultad para tomar censos con que pagar su exención ${ }^{71}$, pero frecuentemente serán ejecuatados por no responder ni a los intereses de los mismos ni a los pagos estipulados con los acreedores de la $\mathrm{Co}-$ rona ${ }^{72}$.

Por otro lado, sabemos que en algunos lugares los clérigos se niegan a pagar y la oligarquías municipales se aprovechan de la situación: a menudo no responden a los pagos, quedándose con el dinero; o no reparten la deuda equitativamente de acuerdo con la cantidad de hacienda; todo ello es objeto de frecuentes denuncias ante el consejo de Hacienda ${ }^{73}$. Muchos pueblos ven

70 Las quejas sobre los nuevos señores serain frecuentes ya desde el principio; así los vecinos de Zofraga dicen que les lleva derechos nuevos y nombra los oficios mientras que antes los ponian ellos y que rnos inquieta y molesta bexa y fatiga' porque no se rediman (A.G.S., Merc y Priv., lg. 336, fol. 1). Los vecinos de Canalejas y Calaveras dicen que $D$. Juan de Tovar, señor de la villa de Villamartin, por odio y enemistad que les habia tomado por haberse tanteado y pretendiendo comprarles «tavia persuadido a muchos vecinos de las dichas villas con dadivar y otras promesas a que revacasen el poder y comision que bavian dado $y$... con amenazas $y$ temores ... tenia a dichas villa alborotadas y escandalizadasy (A.G.S., Merc. $y$ Priv., lg. 272, fol. 20). Los vecinos de Modino y de Redipollos se quejan de Hernando de Frías, acreedor de la Corona, el cual había tomado posesión de estos lugares y no les respetó su derecho a poner los oficios; en Redipollos también denuncian otros abusos, entre los que están no permitirles el aprovechamiento de leña de los montes, consentir a los alguaciles llevar más derechos de los acostumbrados y haber metido más de cien hombres en la cárcel (A.G.S., Exp. de Hac., lg. 322 y 372 respectivamente). Los vecinos de Peñamian, Molinaherrera y Santa Cristina denuncian hechos similares.

71 Esta claúsula figuraba en el acuerdo con los hombres de negocios para facilitar la compra de jurisdicciones. A los pueblos que se redimen se les da licencia para tomar censos, echar por sisa y repartir entre los vecinos la cantidad a pagar, también se dio a veces facultad para vender propios o comunales. Del mismo modo, a los particulares se les permite vender o permutar bienes de su mayorazgo o tomar a censo sobre ellos hasta la cantidad necesaria para poder comprat. Asi se concede a D. Antonio del Castillo Portocarrero para que pudiese comprar la villa de Fermoselle y sus alcabalas hasta en cantidad de 11.000 .000 mrs (A.G.S., Merc. y Priv., lg. 287 , fol. 3 )

72 Así, Fernando de Frías Cevallos se queja ante el Consejo de Hacienda de varios concejos redimidos en el reino de León (Cofiñal, Santiago de las Villas y Redipollos) puesto que no le pagan las cantidades convenidas. A.G.S., Cons. y juntas de Hac., lg. 258.

Hipanta, LVIll/3, nủm. 200 (1998) 1045-1096 
«deshacerse sus haciendas», se despueblan y finalmente deben optar por venderse a un particular que les pague los censos.

$\mathrm{Al}$ menos 15 pueblos redimidos recurren finalmente a esta solución al no poder redimir la deuda principal ni pagar los intereses ${ }^{74}$. Son los siguientes: Castrillo de las Piedras, Pajares, San Martín de la Falamosa, Santa Cristina y Canalejas y Calaveras en León; Villanueva de San Mancio en Palencia; Palacios del Arzobispo e Hinojosa en Salamanca; Mejorada y Pozuelo en Segovia y Fermoselle, Fuentesaúco, Villamor de los Escuderos, Bamba y Sánzoles en Zamora. Suman en total unos 3.440 vecinos, lo que supone un $34 \%$ del total de los vasallos redimidos. Este fenómeno refleja las pésimas condiciones económico-sociales del campesinado castellano en los últimos años del s. XVI y comienzos del s. XVII, que es el momento en que recurren a la autoventa tras soportar la situación durante bastantes años ${ }^{75}$.

73 La villa de Olivares pide que contribuyan en los repartimientos las haciendas de hidalgos y clérigos ya que si no es así no pueden pagar. También los vecinos de Pesadas solicitan al Consejo de Hacienda lo mismo puesto que tienen dificultades para pagar y el lugar se está despoblando. A.G.S., Merc. y Priv. Ig. 312, fol. 7 y Exp. de Hac., lg. 357, fol. 8, respectivamente. Mollorido llegó a ejecutar al capellán de la iglesia que no pagaba, siendo excomulgado este pueblo por el obispo de Salamanca (A.G.S., Cons. y Juntas de Hac., lg. 208, fol. 4) y el lugar de Yugueros (concejo de Modino) se queja de que los forasteros, aunque tienen la mayor parte de las haciendas no quieren pagar (A.G.S., Cons. y Juntas de Hac., lg. 232).

74 Tras licencia concedida por S.M. en 1597 para redimir un censo de 36.000 ducados la villa de Fuentesaúco es comprada por D. Pedro de Deza, arcediano de Calatrava y canónigo de la catedral de Toledo (A.G.S., Dir. Gen. del Tesoro, lg. 284, fol. 3). Villanueva de San Mancio vuelve al monasterio de Sahagún que pagó los censos que debia- en 1596. Mejorada recibe la facultad en 1597 (D.G.T., 284, 23). Pajares pide licencia en 1599; según los vecinos, cuando se tantearon eran 52 vecinos y ahora quedan solo 14; en 1604 el concejo otorga carta de venta a favor de Juan de Balboa Mogrovejo, vecino de Palencia y juez ordinario de la villa de Villalón (D.G.T., 284, 52). Igualmente Canalejas y Calaveras se vendió en 1600 a D. Alvaro Enriquez, marqués de Alcañizas, que redimió los censos; los vecinos argumentan que los dueños de los censos se están haciendo con las haciendas y que de 90 vecinos que habia ahora solo quedan 40 (A.G.S., Merc. y Priv., 272, 20). Por los mismos motivos la villa de Palacios del Arzobispo pide permiso en 1608 para venderse a Doña Isabel de Guzmán y Rojas y a D. Antonio Rodríguez de Herrera, su hijo (D.G.T, 284, 55), La villa de Sánzoles pide licencia en 1607 para venderse al Deán y Cabildo de la catedral de Zamora, su antiguo señor, que redime los censos que tenia (D.G.T., 284, 136). Igual sucede a la villa de Bamba en 1617. La villa de Flinojosa solicita permiso en 1608 y se vende al marqués de San Germán (D.G.T., 286, 12). Villamor de los Escuderos fue rematada en el conde de Vilamor en 1613 (D.G.T., 284, 31). Pozuelo de Belmonte se vendió en 1612 a Cristóbal de Sandoval, duque de Uceda (D.G.T. 284, 71). San Martín de la Falamosa rećbe licencia para venderse en 1613 y lo compra Antonio de Obregón, canónigo de la catedral de León (D.G.T., 286, 23). Santa Cristina la recibe en 1614, siendo el comprador D. Francisco de Villagómez Vivanco, caballero de la orden de Santiago; según los vecinos, el lugar se estaba despoblando ya que tenía cuando se tanteó 113 vecinos y en ese momento tiene 64 y están muy pobres (Merc. y Priv, 332, 16). Castrillo de las Piedras solicita venderse en 1640 estando ya concertado con D. Juan del Valle (Merc. y Priv., 276, 11). Puerto de Santoña pide licencia en 1615 para venderse al duque de Lerma, aunque el acto no debió consumarse dadó que en el s. XVIII consta cono realengo.

75 En cambio en Asturias, donde la redención de los vecinos fue también un fenómeno general, aunque los problemas del pago de la exención fueron importantes, solo hubo un pe-

Hipania, LVIII/3, núm. 200 (1998) 1045-1096 
Si tenemos en cuenta - en base a los datos que conocemos- los vecinos que optaron por la autoventa, los redimidos fueron el $42 \%$ del total de vasallos vendidos, mientras que los que pasaron a señotío secular fueron el $53 \%$ (en el momento de la venta eran el $70 \%$ y $30 \%$ respectivamente). La importancia del señorio secular derivado de la venta de lugares de la Iglesia es a largo plazo mayor que el que reflejan estas cifras, como podemos ver si observamos la evolución del estatuto jurídico de los 127 lugares eclesiásticos enajenados entre el momento de las ventas y a fines del s. XVIII, según datos del nomenclator de Floridablanca: los redimidos pasan de 72 a 42 lugares y los de señorío de 54 a 82 (hemos dejado sin contabilizar algunos lugares por carecer de información). Es decir, el $66 \%$ son de señorío a fines del XVIII, mientras que solo el $34 \%$, pasaron definitivamente a realengo.

Resumiendo, debemos decir que la venta de señorios de la Iglesia fue limitada, ya que de un total de 650 enclaves de señorío eclesiástico que hemos contabilizado en Castilla-León sólo se desmembraron y vendieron 127 77; y del total de enclaves eclesiásticos solo pasaron finalmente a realengo el $7 \%$, mien. tras que el resto sigue perteneciendo a instituciones eclesiásticas o bien pasa a señorío secular. Aunque si tenemos en cuenta el número de vecinos afectados, ventas y redenciones suponen cantidades mayores puesto que tanto los lugares vendidos como los redimidos se corresponden a menudo con los núcleos de más población.

Haciendo un balance de la venta de señoríos eclesiásticos en el siglo XVI podemos decir que aumenta el realengo aunque no contribuye apenas a neutralizar el proceso de señorialización que tiene lugar en Castilla y León a lo largo de la Edad Moderna, en el que un hecho básico será la venta de lugares de realengo que tuvo lugar en el s. XVII, momento de crisis profunda en Castilla. A fines del s. XVIII, según la información del nomenclator de Floridablanca, hay en Castilla-León unos 7.548 lugares -incluyendo los despoblados-, de los que un $38 \%$ son de realengo y un $62 \%$ de señorio.

queño lugar que hubo de optar por la autoventa en 1672. M. A. FAYA, Los señorios eclesiásticos en la Asturias del Siglo XVI, op. cit., pág. 341.

76 A fines del siglo XVIII los lugares de señorio eclesiástico que hemos contabilizado en Castilla-León son 586 incluyendo 118 despoblados, to que supone un $7,8 \%$ del total de lugares. 


\section{SEÑORIOOS ECLESIÁSTICOS EN CASTIULA Y LEÓN ANTES DE LAS DESMEM- BRACIONES}

\begin{tabular}{|l|c|c|}
\hline \multicolumn{2}{|c|}{ LUGARES DE SEÑORIO DEL OBISPO DE AVILA Y SU VECINDAD } \\
\hline \multicolumn{1}{|c|}{ Lugar } & Localizaciôn & Vecindad (1579-80) \\
\hline Bonilla de la Sierra (v.) ${ }^{1}$ & Ávila & $762^{*}$ \\
\hline El Guijo (v.) & Ávila & 68 \\
\hline El Mirón (v) & Ávila & $84^{*}$ \\
\hline El Mironcillo & Ávila & $24^{*}$ \\
\hline Puente del Congosto (v.) & Ávila & $97 *$ \\
\hline San Bartolomé de Corneja (v.) & Ávila & 36 \\
\hline Vadillo de la Sierra (v) & Ávila & 425 \\
\hline Villanueva del Campillo (v.) & Ávila & 327,5 \\
\hline
\end{tabular}

$\mathrm{v}=$ villa

* Son datos del censo de 1591. La villa de Bonilla tiene 248 vecinos y los lugares de su jurisdicción 514.

Jugares de la jurisdicción de esta villa son: Mescgar, Casasola, Malpartida, las casas de Chicapicrna, Jas Becedillas; 'Tórtoles, Cabezas Pajareros y la mitad del lugar de Las Casas del Puerto.

\begin{tabular}{|l|c|c|}
\hline \multicolumn{2}{|c|}{ LUGARES DE SEÑORIO DEL ARZOBISPO DE BURGOS Y SU VECINDAD } \\
\hline \multicolumn{1}{|c|}{ Lugar } & Localización & Vecindad \\
\hline Pie de Concha $(\mathrm{v})$, Bárcena y Cobejo & Santander & 101,5 \\
\hline Porciles & sin localizar & 32,5 \\
\hline
\end{tabular}

Según el nomenciator de Fioridablanca el arzobispo de Burgos tiene en el s. XVIII los lugares de Arcos, Villasur de Según el nomenciator de Fioridablanca el arzobispo de Burgow tiene en el s. XVin los lugares de
Hetreros y Villafruela. Es posible que ya sean suyos cn els. XVl; en 1591 ascienden a 341 vecinos. 


\begin{tabular}{|c|c|c|c|}
\hline \multicolumn{4}{|c|}{$\begin{array}{l}\text { LUGARES DE SEÑORIOO DE OTRAS INSTTTUCIONES ECLESIÁSTICAS EN EL } \\
\text { ARZOBISPADO DE BURGOS Y EN EL OBISPADO DE CALAHORRA Y SU VECINDAD }\end{array}$} \\
\hline Titular & Lugar & Localizaciôn & Vecindad \\
\hline Calahorta, obispo de & Inestrillas (v.) & Logroño & 101,5 \\
\hline \multirow[t]{6}{*}{ Hospital del Rey } & $\begin{array}{l}\text { Arroyal, San Mamés, Marmellar } \\
\text { de Arriba, Villacienco, } \\
\text { Villaermera, Cardeñadijo y } \\
\text { Villabascones (en la jurisdicción } \\
\text { de Burgos) }\end{array}$ & Burgos & 165 \\
\hline & $\begin{array}{l}\text { Colina, barrio de (merindad de } \\
\text { Montedeoca)* }\end{array}$ & Burgos & 7 \\
\hline & $\begin{array}{l}\text { Congosto, Lorilla y Tablada (en } \\
\text { la merindad de Villadiego) }\end{array}$ & Burgos & 48 \\
\hline & $\begin{array}{l}\text { Madrigalejo y Moncalvillo } \\
\text { (merindad de Sto.Domingo de } \\
\text { Silos) }\end{array}$ & Burgos & 115 \\
\hline & $\begin{array}{l}\text { Pedrosa de Candemuño } \\
\text { (merindad de Candemuño) }\end{array}$ & Burgos & 17 \\
\hline & $\begin{array}{l}\text { Quintanilla de Sobresierra y } \\
\text { Castrillo de Rucios (merindad } \\
\text { de Río Hubierna) }\end{array}$ & Burgos & 61 \\
\hline Puerto de Santoña, Iglesia de & Moncalán & Santander & $15^{* *}$ \\
\hline Santander, Abadía de & $\begin{array}{l}\text { Sancibrián, Bezana, Maoño y } \\
\text { Azoños }\end{array}$ & Santander & 131 \\
\hline Santillana, Abadía de & La Marina, lugares del valle de & Santander & $405^{* *}$ \\
\hline
\end{tabular}

* Jurisdicción a prevención con Lara y Belorado.

** En el primer caso son datos de 1954; en el segundo corresponden al censo de 1591.

Son los lugares de La Busta, Caranceja, Cerrazo, Cortiguera, Golbardo, Hinojedo, Suances, Puente-Avios, Casar, Helguera, Villapresente, Novales, Cobreces, Queveda, Tagle, Ruiloba, La Rabia, Ibio, San Pedro, Lloreda y Fresnedo, Mercadai, Orcria, Puente, 'loporias, Ubiarco y veguilla. El censo de 1591 diec que el número de vasallos que posec el abad de Santillana en el valle de $\mathrm{La}$ Marina, donde estin incluidos los citados y algunos más, asciende a 405.

En el s. XVIII el obispo de Calahorra ticne el lugar de Arnedilla que quíź́ posea ya en el s. XVI; según cl censo de 1591 ticne 240 vecinos:; por su parte, la Iglesia de Burgos posee los de Valpuesta, Madrigal del Monte y San Quirce, los cuales suben en $159 t$ a 173 vecinos.

En cuanto al número de vasallos de monasterios en Burgos, Cantabria y La Rioja (arzobispado de Burgos y obispado de Calahorra) asciende a 9.204 (5.907 cn Burgos y $3.297 \mathrm{en} \mathrm{logrono),} \mathrm{discribuídos} \mathrm{así:} \mathrm{montsterio} \mathrm{de} \mathrm{Nâjera} 1.804$ vecinos; Las l. Luelgas de Burgos: 1.593; Oña: 1.292; S. Pedro de Afrlanza: 718; S. Millán de la Cogolla: 672; Valvanera: 514; Herce: 457; Santo Domingo de Silos: 445; S. Pedro de Cardeña: 330; La Vid: 240; Santz Clam de Medina de Pornar: 235;

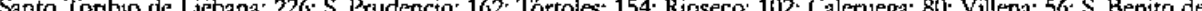
Sahagún: 52; Obarenes: 21; Bugedo: 17 y Eil Espino: 29. E1 total de enelaves manásticos es de 176 (147 en Burgos y Cantabrin y 29 en La Rioja). 


\section{LUGARES DE SEÑORÍO DEL OBISPO DE LEÓN Y SU VECINDAD}

\begin{tabular}{|c|c|c|}
\hline Lugar & Localización & $\begin{array}{l}\text { Recuento devecindad } \\
\text { para la venta }\end{array}$ \\
\hline Abelgas (v) & León & 71,5 \\
\hline Boada de Campos (vi)* & Palencia & 122,5 \\
\hline Caminayo & León & $10^{* *}$ \\
\hline $\begin{array}{l}\text { Canalejas, Villaverde de Abajo, } \\
\text { Castrillino y Villanueva del Arbol }\end{array}$ & León & $75^{* *}$ \\
\hline Castrovega & León & 71,5 \\
\hline Castrotierra & León & 71 \\
\hline Celadilla & León & 68 \\
\hline Curueño, encartación $\mathrm{de}^{2}$ & León & 242,5 \\
\hline Las Arrimadas, concejo de ${ }^{3}$ & León & 115,5 \\
\hline Liegos (v) & León & 42,5 \\
\hline Matallana & León & 112,5 \\
\hline Modino, concejo de ${ }^{4}$ & Leôn & 260 \\
\hline Molinaherrera (v) & León & 167 \\
\hline Pajares de Campos (v) & Valladolid & 52,5 \\
\hline Peñamián, concejo de ${ }^{5}$ & León & 309,5 \\
\hline Santa Cristina & León & 111,5 \\
\hline Santiago de las Villas (v) & Leán & $48^{* *}$ \\
\hline Valdeteja y La Braña & León & 67 \\
\hline Valdevimbre (v) & León & 55 \\
\hline Villadangos & León & 69,5 \\
\hline Villacarlón (v) & Valladolid & 119,5 \\
\hline
\end{tabular}

* Jurisuicción compartida con otro titular. Compartido con el Dén y Cabildo de la catedral de Lcón.

** Datos claborados con fuentes diversas.

Son lugares del valle de Torí, en el cual hay un total de 22 lugares; otro es de la abadía de Arbás y cl resto se reparten cntre el monasterio de San Isidro y el conde de Benavente. Este, aparte de los lugares propios, comparte la jurisdicciün çn el resto de los lugares a prevención con los titulares eclesiásticos

Incluye los lugares de Valdepiélago, Ia Vecilla, La Mata, Montuerto, Otero, Ranedo, Correcitias, Noceda, Valyerde, Villarresil y Valdorria.

3. Incluye las lugares de Acisa, Barrillos Santa Colomba y Laiz.

+ Incluye los lugares de Modino (30,5 vecinos), Cistierna (85), Quintana de la Pcra (25,5), Alejico (13), Saclices $(24,5)$, plleros (33,5), Sotillos (23) y la mitad del lugar deYugueros (25).

Incluye los lugares de Camposolillo (40 vecinos), Solle (82,5), Ricro (40), primajas (19,5), Pallide (51), Redipollos (62) San Cibrian $(14,5)$.

En el nomenclator de Floridablancia se citan también como del'obispo los lugares siguientes: condado de Colle (Colle, Jelechas, Grandoso, La Llama, y Vozmediano), San Cibrian del Condado y los lugares del conecjo de Periamian que no se desmembraron (Armada, Campillo, Ferreras, Lodares, Oroncs, Quintanilla, Rucayo, Valuschuesa, Vegamian, Vicgo y Utrero). Es muy posible que ya fucran suyos en al s. XVI; scgún los datos del vecindario de 1587 y del censo de 15121 ascienden 2515 vecinos.

Hispania, 1.VII1/3, núm. 200 (1998) 1045-1096 


\begin{tabular}{|l|c|c|}
\hline \multicolumn{2}{|c|}{ LUGARES DE SEÑORIO DEL OBISPO DE ASTORGA Y SU VECINDAD } \\
\hline Lugar & Localización & $\begin{array}{c}\text { Recuento de vecindad } \\
\text { para la venta }\end{array}$ \\
\hline Camarzana & Zamora & $30^{*}$ \\
\hline junquera & Zamora & $28^{*}$ \\
\hline La Carrera y Villaobispo & León & 35 \\
\hline Puebla de Valverde & Zamora & $19^{*}$ \\
\hline Otero (v) & León & 37 \\
\hline San Adrián del Valle & León & $70^{*}$ \\
\hline San Pedro de Zamudia & Zamora & $24^{*}$ \\
\hline Santa Colomba & Zamora & $28^{*}$ \\
\hline Santa Martá & Zamora & $35^{*}$ \\
\hline Santibáñez & Zamora & $35^{*}$ \\
\hline Val de San Román & León & 107,5 \\
\hline Verdenosa & Zamora & $52^{*}$ \\
\hline
\end{tabular}

* Son datos del censo de 1591.

Según el nomenclator de Floridablanca son suyos también los lugares de Val de San Lorenzo, Val de Espino, Val de Rey, Brazuclo, Curillas, Matanza, Prado de Rey, Rodrigatos, Antoñán del Valle, Maluenga, Roperuelos del Páramo, San Martin de Torres y Villaverde en el partido de Ieon; en el partido de Ponfermada tienc los de Fonfría, Matavencro, Puibucna, San liacundo, Santa Cruz de Montes, Santa Marina de Montes, Santibánez de Montes, 'Torre, Lucillo, Busnadiego, Chana de la Somoza, Filiel, Luyego, l'iedras-albas, Pobladura de la Sierra y Villalibre. Es de suponer que estos lugares ya fucran del obispo en el siglo XVI; según el ecnso de 1591 ascicnde su vecindad a unos 1.365 vecinos. 


\begin{tabular}{|c|c|c|c|}
\hline \multicolumn{4}{|c|}{$\begin{array}{l}\text { LUGARES DE SENYORIO DE OTRAS INSTITUCIONES ECLESIASTICAS } \\
\text { EN LEON Y SU VECINDAD }\end{array}$} \\
\hline Titular & Lugar & Localización & Vecindad \\
\hline Arbás, abadia de & $\begin{array}{l}\text { Arbás, concejo de (Casares, } \\
\text { Cubillas, Pendilla, Tonin, } \\
\text { Vegalamosa y Viadangos) } \\
\text { Garrafe }\end{array}$ & $\begin{array}{l}\text { León } \\
\text { León }\end{array}$ & $\begin{array}{l}272 \\
30^{*}\end{array}$ \\
\hline Astorga, Deán y Cabijdo de ${ }^{1}$ & $\begin{array}{l}\text { Congosto } \\
\text { San Andrés de las Puentes }\end{array}$ & $\begin{array}{l}\text { León } \\
\text { León }\end{array}$ & $\begin{array}{l}65 \\
45^{*} \\
\end{array}$ \\
\hline León, Deán y Cabildo de ${ }^{2}$ & $\begin{array}{l}\text { Cillanueva } \\
\text { Fuentes de los Oteros (v) } \\
\text { Grajal } \\
\text { Gusendos } \\
\text { Villarmeriel }\end{array}$ & $\begin{array}{l}\text { León } \\
\text { León } \\
\text { León } \\
\text { León } \\
\text { León }\end{array}$ & $\begin{array}{l}33,5 \\
23 \\
67 \\
132 \\
31^{*}\end{array}$ \\
\hline Obispo de Oviedo & $\begin{array}{l}\text { Folledo } \\
\text { Las Huergas y el Millar } \\
\text { San Martín de la Falamosa }\end{array}$ & $\begin{array}{l}\text { León } \\
\text { León } \\
\text { León }\end{array}$ & $\begin{array}{l}47,5 \\
21,5 \\
97,5\end{array}$ \\
\hline Ribasdesil, Arcediano de ${ }^{3}$ & $\begin{array}{l}\text { Palaciosmil (v) } \\
\text { Toreno (v), Librán, San } \\
\text { Pedro, Santa Leocadia, } \\
\text { Matarrosa y Barrio }\end{array}$ & $\begin{array}{l}\text { León } \\
\text { León }\end{array}$ & $\begin{array}{l}28 \\
207,5\end{array}$ \\
\hline Santiago, Arzobispo de ${ }^{4}$ & $\begin{array}{l}\text { Pieros } \\
\text { Villayandre }\end{array}$ & $\begin{array}{l}\text { León } \\
\text { León }\end{array}$ & $\begin{array}{l}27 \\
87 *\end{array}$ \\
\hline Santiago de Peñalba, Abad de ${ }^{5}$ & Castrillo de las Piedras & León & 56 \\
\hline
\end{tabular}

* San datos claborados a partir de varias fuentes.

En el sigho XVIII, según el nomenclator de Floridablanca, tiene también los lugares de Espina de Tremor, Farvalles y Santa Colomba de Turienzo; segín el censo de 1591 suben estos lugares a 118 vecinos.

Según cl documento de la cita anterior en cl s. XVIII posee además los lugares de Guerga del Rio, Riego del Monte, Villanueva de las Manzanas y Villarente, compartido éste iltimo con el marqués de Fonthoyuelo; suben a unos 86 vecinos seguin datos de 1591

En el siglo XVIJJ se citan también los lugares de Faro y San Justo de Cabanillas; su vecindad asciende cn 1591 a 63

yecinos. 65 vecinos.

En cl nomenchator de Floridablanca constan como suyos los lugares de Santiago de Peñalba y Bouzas; suben a unos 48 recioos en 1591 .

En cuanto a los monasterios cuentan con unos 4.502 vasallos en los obispados de Loón y Astorga distribuidos así: monasterio de San Isidro de León: 980 vecinos; Espinareda: 953; Carracedo; 484; San Benito de Sahagún: 390; Otero de las Dueñas: 366; San Pedro de Montes: 274. Carrizo: 240; Valdediós: 142; San Clodio: 108; Nagales: 104; Sandoval: 93; Carbajal: 75; Roncesvalles: 50; Gradefes: 60; Benevivere: 4); $\mathrm{S}$. Migucl de las Dueñas; 43 ; $\mathrm{S}$ Pedro de Duenas; $40 ; \mathrm{S}$ julián del Montc: $20 ; \mathrm{S}$. Pedro de Fslonza: 20 y S. Juan de Corias: 11 . LI númeto de enclaves monásticos contabilizados asciende a 122 .

IItphanta, LVIII/3, núm. 200 (1998) 1045-1096 


\begin{tabular}{|c|c|c|c|}
\hline \multicolumn{4}{|c|}{ LUGARES DE SEÑORIO DEL OBISPO DE OSMA Y SU VECINDAD } \\
\hline Lugar & Localización & $\begin{array}{l}\text { Vecindad } \\
\text { (1574) }\end{array}$ & Vecindad (1583) \\
\hline Abéjar & Soria & 107 & 180 \\
\hline Aylagas & Soria & 29 & $30(25 \mathrm{ve}, 5 \mathrm{vi})$ \\
\hline Aldehuela & Soria & 22 & -3 \\
\hline Barcebal & Sona & 26 & $19(13 \mathrm{pe}, 3 \mathrm{vi}, 3 \mathrm{mh})$ \\
\hline Boos & Soria & 58 & $47(39 \mathrm{pe}, 6 \mathrm{vi}, 2 \mathrm{mh})$ \\
\hline Burgo de Osma (v) & Soria & 288 & 255 \\
\hline Cabrejas (v.) & Soria & 110 & 190 \\
\hline Cantalucía & Soria & 17,5 & $23(12 \mathrm{pe}, 2 \mathrm{vi}, 9 \mathrm{mh})$ \\
\hline Cubilla & Soria & 21,5 & 23 \\
\hline Cubillos & Soria & 17 & $24(17$ ve, 4 vi, $3 \mathrm{mh})$ \\
\hline Fuentecantales & Soria & 23,5 & $20(16$ ve, 4 vi) \\
\hline Gómara (v.) & Soria & 158 & 190 \\
\hline Herrera & Soria & 29,5 & 30 (27 ve, 3 vi) \\
\hline Muriel de la Fuente & Soria & 20 & 22 \\
\hline Muriel Viejo & Soria & 18,5 & 17 \\
\hline Nafria & Soria & 25,5 & $31(24$ ve, 5 vi, $2 \mathrm{mh})$ \\
\hline Quintanas Rubias (v) & Soria & 36 & 39 (29 ve, 10 vi) \\
\hline Rejas de Ucero & Soria & 28 & $28(20$ ve, 5 vi, $3 \mathrm{mh})$ \\
\hline Santiuste & Soria & 26,5 & 12 \\
\hline Santuy (v.) & Soria & 37 & $44(39$ ve, 5 vi) \\
\hline Sotos & Sotia & 27 & $28(17 \mathrm{ve}, 3 \mathrm{vi}, 8 \mathrm{mh})$ \\
\hline Talveila & Soria & 20 & 26 \\
\hline Torralba & Soria & 35,5 & 30 \\
\hline Ucero (v) & Soria & 45 & $47(29$ ve, 11 vi, $7 \mathrm{mh})$ \\
\hline Valdeavellano & Soria & 18 & $22(15 \mathrm{ve}, 1 \mathrm{vi}, 6 \mathrm{mh})$ \\
\hline Valdelinares & Soria & 11 & $14(10 \mathrm{ve}, 4 \mathrm{mh})$ \\
\hline Valdelubiel & Soria & 14 & $19(10$ ve, $9 \mathrm{mh})$ \\
\hline Valdemaluque & Soria & 30,5 & 34 (19 ve, 10 vi, $5 \mathrm{mh})$ \\
\hline Valdenebro & Soria & 16 & $13(10$ ve, 3 vi $)$ \\
\hline Valderrubiales & Soria & 3 & $3(3 \mathrm{ve})$ \\
\hline Valverde & Soria & 23 & 20 (16 ve, 2 vi, $2 \mathrm{mh})$ \\
\hline Velilla (v.) & Soria & 19,5 & $18(16$ ve, 2 vi) \\
\hline
\end{tabular}

No nos constan scroríos de otras instituciones eclesiásticas en la provincia de Soria salvo 387 vasallos de monasterios: S. Pedro de Arlanza con 291 y Fuencaliente con 96.

Hi.pania, LVIII/3, nưn 200 (1998) 105-1096 


\begin{tabular}{|c|c|c|}
\hline \multicolumn{3}{|c|}{ LUGARES DE SEÑORIO DEL OBISPO DE PAIENCIA Y SU VECINDAD } \\
\hline Lugar & Localización & Vecindad (1582) \\
\hline Areños y Casavegas & Palencia & 20 \\
\hline Bárago y Sobtado* & Santander & 36 \\
\hline Bedoya (valle de), Salarzón y Trillayo* & Santander & 42 \\
\hline Bimón y Tresbarrios* & Santander & 38 \\
\hline Castro & Santander & 35 \\
\hline Cotillos* & Santander & 10 \\
\hline Grijota (v) & Palencia & 100 \\
\hline La Lastra $(v)^{*}$ & Palencia & 20 \\
\hline $\operatorname{Magaz}(\nabla)$ & Palencia & 80 \\
\hline Mazariegos (v.) & Palencia & 317 \\
\hline Palacios del Alcor (v.) $)^{*}$ & Palencia & 80 \\
\hline Salceda* & Santander & 14 \\
\hline San Mamés* & Santander & 18 \\
\hline San Salvador (v.) & Palencia & 40 \\
\hline Santa Cecilia (v) & Palencia & 65 \\
\hline Santa Cruz de Boedo (v) & Palencia & 50 \\
\hline Tresabuela* & Santander & 14 \\
\hline Villajimena (v.) & Paiencia & 57 \\
\hline Villalobón (v) & Palencia & 80 \\
\hline Villamartín (v.) & Palencia & 90 \\
\hline Villamurtel (v.) & Palencia & 100 \\
\hline
\end{tabular}

* Jurisdicción compartida con otro titular. En la villa de Ia Lastra cl Obispo comparte la jurisdicción con la villa de Cervera, que es del conde de Sirucla; en Palacios del Alcor la comparte con la villa de $A$ studillo, del conde de Castro. En el resto de los lugares sólo teene la jurisdicción civil; la criminal la cicree la villa de Potes, que es del duque del Infantado.

Hi.gonia, I,VIII/3, núm. 201 (1998) 1045-10\%6 


\begin{tabular}{|c|c|c|c|}
\hline \multicolumn{4}{|c|}{$\begin{array}{l}\text { LUGARES DE SEÑORIO DE OTRAS INSTITUCIONES ECLESIÁSTICAS EN EL } \\
\text { ARZOBISPADO DE PALENCIA Y SU VECINDAD }\end{array}$} \\
\hline Titular & Lugar & Localizaciốn & $\begin{array}{l}\text { Vecindad } \\
(\mathbf{1 5 8 2})\end{array}$ \\
\hline Hérmedes, Abad de & Hérmedes & Palencia & 35 \\
\hline Husillos, Colegiata de & $\begin{array}{l}\text { Husillos (v) } \\
\text { Villaldavin (v) }\end{array}$ & $\begin{array}{l}\text { Palencia } \\
\text { Palencia } \\
\end{array}$ & $\begin{array}{l}50 \\
30 \\
\end{array}$ \\
\hline Lebanza, Abadia de & $\begin{array}{l}\text { Lebanza* } \\
\text { Polentinos* } \\
\text { Estalaya* } \\
\end{array}$ & $\begin{array}{l}\text { Palencia } \\
\text { Palencia } \\
\text { Palencia } \\
\end{array}$ & $\begin{array}{l}24 \\
30 \\
15 \\
\end{array}$ \\
\hline $\begin{array}{l}\text { San Antolín de Palencia, } \\
\text { Hospital de }\end{array}$ & Pedraza de Campos (v) & Palencia & 200 \\
\hline Santiago, Arzobispo de & Ledigos & Palencia & 67 \\
\hline Siguenza, Obispo de & Padilla de Campos & sin Jocalizar & 0 \\
\hline Toledo, Arzobispo de & $\begin{array}{l}\text { San Cristóbal de Boedo (v.) } \\
\text { Vullaumbrales (v) }\end{array}$ & $\begin{array}{l}\text { Palencia } \\
\text { Palencia }\end{array}$ & $\begin{array}{l}46^{* *} \\
250 \\
\end{array}$ \\
\hline Valladolid, Abad de & $\begin{array}{l}\text { Olivares }(v \text {.) } \\
\text { Peñalba de Duero }(v)^{*} \\
\text { Villabáñ̃ez }(v)^{*}\end{array}$ & $\begin{array}{l}\text { Valladolid } \\
\text { Valladolid } \\
\text { Valladolid }\end{array}$ & $\begin{array}{r}300 \\
30 \\
250\end{array}$ \\
\hline
\end{tabular}

* Jurisdicción compartida con otro tinular. In los lugares de la abadía de I.ebanza la jurisdicoión es compartida con la vilia de Cervera. El abad de Valladolid comearte la jurisdicción de la villa de Peralba de Ducro con D. I'édro Gasca de la Vega y la de Villabínezz con D. Pedro Gasca y D. Pedro de Zúñiga.

** Son datos del censo de 1501 .

En cuanto a los vasallos de monasterios ascienden en el obispado de Palencia a 2.260 distribuidos asi: S. Benito de Sahagún: 605 vecinos; Las luelgas de Burgos: 430; S. Andrés de Arroyo: 193; Santa Clarn de Tordesillas: 180; Aguilar de Campoo: 155; Las Hucigas de Valladolid: 125; S. Zoilo de Carrión: 125; Vega: 121; Valbuena: 75; S. Eliforso de Toro: 50; Calabazanos: 48; S. Isidro de Ducrias: 23; Otero de las Dueñas: 40, S. Pedro de Cardeña: 40; Santa Cruz de Palencia: 25; Retuerta: 15 y Oña: 10. Li monasterio de Benavides ticne jurisdicción sobre cl lugar donde estŕ ubicado, aunque no tiene vasallos. Los enclaves monásticos contabilizados en Palencia y Valladolid ascienden a 59.

\begin{tabular}{|c|c|c|}
\hline \multicolumn{3}{|c|}{ LUGARES DE SEÑORİO DEI, OBISPO DE SAIAMANCA Y SU VECINDAD } \\
\hline Lugar & Localizaciôn & Vecindad (1574) \\
\hline Cantalapiedta (v.) & Salamanca & 519 (383 pe, 9 hi, $11 \mathrm{cl}, 103 \mathrm{vi}, 13 \mathrm{mb})$ \\
\hline Carrascal (v.), Los Huelmos y Casasolilla & Salamanca & 121 \\
\hline Mollorido (v) & Salamanca & $30(23 \mathrm{ve}, 1 \mathrm{cl}, 5 \mathrm{vi}, 1 \mathrm{mh})$ \\
\hline San Martín del Castañar (v.) & Salamanca & $368(245 \mathrm{pe}, 11 \mathrm{hi}, 2 \mathrm{cl}, 92 \mathrm{vi}, 18 \mathrm{gm})$ \\
\hline San Pelayo y Palacinos (v.) & Salamanca & 49 \\
\hline Tejares (v.) & Salamanca & 86 \\
\hline Topas (v) & Salamanca & 95 (69 ve, 26 vi) \\
\hline Vitigudino (v.) & Salamanca & 490 \\
\hline Zofraga (v.) & Salamanca & 32 \\
\hline
\end{tabular}

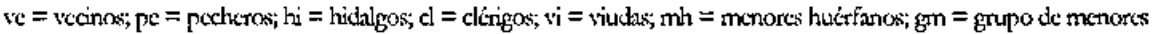

Hiģasnia, LVIII/3, núm. 200 (1998) 1045-1096 


\begin{tabular}{|c|c|c|c|}
\hline \multicolumn{4}{|c|}{$\begin{array}{l}\text { LUGARES DE SEÑORIO DE OTRAS INSTTTUCIONES ECLESIÁSTICAS } \\
\text { EN SAIAMANCA Y SU VECINDAD }\end{array}$} \\
\hline Titular & Lugar & Localizaciôn & $\begin{array}{l}\text { Vecindad } \\
(1574-1584)\end{array}$ \\
\hline $\begin{array}{l}\text { Ciudad Rodrigo, } \\
\text { Obispo de }\end{array}$ & $\begin{array}{l}\text { Bermellar (v.) } \\
\text { Lumbrales (v.) y El Madroñal, } \\
\text { su aldea } \\
\text { Fregeneda (v.) } \\
\text { Hinojosa (v.) } \\
\text { La Redonda } \\
\text { Monsagro } \\
\text { Sepúlveda } \\
\end{array}$ & $\begin{array}{l}\text { Salamanca } \\
\text { Salamanca } \\
\text { Salamanca } \\
\text { Salamanca } \\
\text { Salamanca } \\
\text { Salamanca } \\
\text { Salamanca } \\
\end{array}$ & $\begin{array}{c}112 \\
\text { (89 ve,2 cl,17 vi, } 4 \mathrm{gm}) \\
705 \\
(511 \mathrm{ve}, 10 \mathrm{cl}, 143 \mathrm{vi}, 41 \mathrm{gm}) \\
265 \\
427 \\
81^{* *} \\
12^{* *} \\
23^{* *}\end{array}$ \\
\hline $\begin{array}{l}\text { Ciudad Rodrigo, } \\
\text { Deán y Cabildo de }\end{array}$ & $\begin{array}{l}\text { Santispiritus, el Bocara y } \\
\text { Valdelazarza }\end{array}$ & Salamanca & $127^{* * *}$ \\
\hline $\begin{array}{l}\text { Salamanca } \\
\text { Deán y Cabildo de }\end{array}$ & $\begin{array}{l}\text { Buenamadre (v.) } \\
\text { Mercadillo (v.)* } \\
\text { San Cristóbal del Monte (v.) }\end{array}$ & $\begin{array}{l}\text { Salamanca } \\
\text { Salamanca } \\
\text { Salamanca } \\
\end{array}$ & $\begin{array}{r}35 \\
4 \\
2 \\
\end{array}$ \\
\hline $\begin{array}{l}\text { Santiago, } \\
\text { Arzobispo de }\end{array}$ & $\begin{array}{l}\text { Aldehuela } \\
\text { Aldeanueva del Arzobispo (v) } \\
\text { Herguijuela (v.) } \\
\text { Palacios del Arzobispo (v.) } \\
\text { Vilvestre (v) } \\
\text { Yecla (v.) }\end{array}$ & $\begin{array}{l}\text { Salamanca } \\
\text { Salamanca } \\
\text { Salamanca } \\
\text { Salamanca } \\
\text { Salamanca } \\
\text { Salamanca }\end{array}$ & $\begin{array}{c}65 \\
226 \\
229 \\
115 \\
345^{* *} \\
249^{* *}\end{array}$ \\
\hline
\end{tabular}

* Jurisdicción compartida con otro titular. La jurisdicción crirninal es del duque de Albuquerque. ** Son datos del censo de 1591 .

Nos consta que en el siglo XVIII el Deán y Cabildo de Salamanca tiene también el lugar de Gansinos y el obispo de Ciudad Rodrigo la villa de Saucedilla; en 1591 ascienden estos lugares a 264 vecinos.

Respecto a vasallos de monasterios nos consta hay en Salamanca 114: El monasterio de S. Vicente ticne 106 vecinos y el de Santa María de Portaçelj 8.

\begin{tabular}{|c|c|c|}
\hline \multicolumn{3}{|c|}{ LUGARES DE SEÑORÍO DEI. OBISPO DE SEGOVIA Y SU VECINDAD } \\
\hline Lugar & Localización & Vecindad (1574) \\
\hline Caballar (v.) & Segovia & 145 (43 ve, $1 \mathrm{cl}, 15$ vi, $86 \mathrm{mh})$ \\
\hline Fuentepelayo (v) & Segovia & 496 (304 ve, $6 \mathrm{cl}, 54 \mathrm{vi}, 132 \mathrm{mh})$ \\
\hline Lagunillas (v.) & Segovia & 153 (63 pe, 1 hi, $2 \mathrm{cl}, 22 \mathrm{vi}, 65 \mathrm{mh})$ \\
\hline Mejorada (v) & Madrid & 133 \\
\hline Mojados (v.) & Valladolid & 393 (199 pe, $22 \mathrm{hi}, 5 \mathrm{cl}, 42 \mathrm{vi}, 125 \mathrm{mh})$ \\
\hline Navares de las Cuevas (v.) & Segovia & $87(53$ pe, 1 hi, 1 cl, 6 vi, $26 \mathrm{mh})$ \\
\hline Pozuelo (v) & Madrid & $536(261 \mathrm{pe}, 1 \mathrm{hi}, 5 \mathrm{cl}, 78 \mathrm{vi}, 191 \mathrm{mh})$ \\
\hline Turégano (v.) & Segovia & 456 (180 pe, $12 \mathrm{hi}, 6 \mathrm{cl}, 43 \mathrm{vi}, 215 \mathrm{mh})$ \\
\hline Veganzones (v) & Segovia & 272 (112 ve, $2 \mathrm{cl}, 35 \mathrm{vi}, 123 \mathrm{mh})$ \\
\hline
\end{tabular}

Hipantia, LVIII/3, núm. 200 (1998) 1045-1096 


\begin{tabular}{|c|c|c|c|}
\hline \multicolumn{4}{|c|}{ LUGARES DE SEÑORIO DEL OBISPO DE ZAMORA Y SU VECINDAD } \\
\hline Lugar & Localizacion & Vecindad (1574) & Vecindad (1582) \\
\hline Almendra (v.) & Zamora & $\begin{array}{c}25 \\
(17 \mathrm{pe}, 2 \mathrm{cl}, 4 \mathrm{vi}, 2 \mathrm{mh})\end{array}$ & $\begin{array}{c}21 \\
(15 \mathrm{ve}, 2 \mathrm{cl}, 4 \mathrm{vi})\end{array}$ \\
\hline $\begin{array}{l}\text { Fermoselle (v.) y Pinilla, } \\
\text { Cibanal y Hornillos, } \\
\text { sus aldeas }\end{array}$ & Zamora & $\begin{array}{c}669 \\
(474 \mathrm{ve}, 10 \mathrm{cl}, 129 \mathrm{vi}, 56 \mathrm{mh})\end{array}$ & $(476 \mathrm{ve}, 1 \mathrm{cl}, 147 \mathrm{vi})$ \\
\hline Fresno de la Ribera (v) & Zamora & (54 ve, 15 vi, $3 \mathrm{mh})$ & $\begin{array}{c}64 \\
(48 \mathrm{ve}, 16 \text { vi) }\end{array}$ \\
\hline Fresno de Sayago (v.)* & Zamora & 92 & $\begin{array}{c}73 \\
(56 \mathrm{ve}, 17 \mathrm{vi}) \\
\end{array}$ \\
\hline Fuentesaúco (v.) & Zamora & $\begin{array}{c}830 \\
(599 \mathrm{pe}, 15 \mathrm{hi}, 18 \mathrm{~d}, 160 \mathrm{vi}, 38 \mathrm{mh}) \\
\end{array}$ & $\begin{array}{c}798 \\
(620 \text { ve, } 1 \mathrm{cl}, 177 \mathrm{vi}) \\
\end{array}$ \\
\hline Manganeses (v.) & Zamora & $\begin{array}{c}219 \\
\text { (141 pe, } 5 \mathrm{hi}, 2 \mathrm{cl}, 38 \mathrm{vi}, 33 \mathrm{mh}) \\
\end{array}$ & $\begin{array}{c}214 \\
(167 \mathrm{ve}, 3 \mathrm{cl}, 44 \mathrm{vi})\end{array}$ \\
\hline Mayalde (v.) & Zamora & $\begin{array}{c}67 \\
(55 \mathrm{ve}, 9 \mathrm{vi}, 3 \mathrm{mh}) \\
\end{array}$ & $\begin{array}{c}63 \\
\text { (40 ve, } 1 \mathrm{cl}, 22 \mathrm{vi})\end{array}$ \\
\hline Moraleja de Sayago $(v)^{*}$ & Zamora & $\begin{array}{c}73 \\
(57 \mathrm{ve}, 14 \mathrm{vi}, 2 \mathrm{mh})\end{array}$ & $\begin{array}{c}64 \\
(47 \mathrm{ve}, 17 \text { vi) } \\
\end{array}$ \\
\hline Venialbo (v.) & Zamora & $\begin{array}{c}350 \\
(228 \mathrm{ve}, 5 \mathrm{cl}, 64 \text { vi, } 53 \mathrm{mh}) \\
\end{array}$ & $\begin{array}{c}260 \\
(202 \mathrm{ve}, 3 \mathrm{cl}, 55 \mathrm{vi})\end{array}$ \\
\hline Villalcampo (v.) & Zamora & $\begin{array}{c}173 \\
(97 \mathrm{ve}, 40 \mathrm{vi}, 36 \mathrm{mh}) \\
\end{array}$ & $\begin{array}{c}115 \\
(85 \mathrm{ve}, 30 \mathrm{vi}) \\
\end{array}$ \\
\hline $\begin{array}{l}\text { Villamor de los } \\
\text { Escuderos (v.) }\end{array}$ & Zamora & $\begin{array}{c}249 \\
\text { (166 ve, } 3 \mathrm{cl}, 46 \text { vi, } 34 \mathrm{mh})\end{array}$ & $\begin{array}{c}211 \\
(170 \mathrm{ve}, 1 \mathrm{cl}, 40 \mathrm{vi})\end{array}$ \\
\hline
\end{tabular}

* Jurisdicción compartida. Una parte de la villa de Fresno de Sayago depende de la jurisdicción de la ciudad de Zamora y otra parte del obispo. En Moraleja de Sayago el Obispo tiene únicamente la jurisdicción civil, micntras la criminal es de la villa de Ledesma cuyo titular es el duque de Albuquerque.

\begin{tabular}{|c|c|c|c|}
\hline \multicolumn{4}{|c|}{ LUGARES DE OTRAS INSTITUCIONES ECIESIÄSTICAS EN ZAMORA Y SU VECINDAD } \\
\hline Titular & Lugar & Localización & Vecindad (1582) \\
\hline $\begin{array}{l}\text { Santiago, } \\
\text { arzobispo de }\end{array}$ & $\begin{array}{l}\text { Atquilinos (v.) } \\
\text { Fonfría (v.) }\end{array}$ & $\begin{array}{l}\text { Zamora } \\
\text { Zamora }\end{array}$ & $\begin{array}{r}86 \\
55^{*} \\
\end{array}$ \\
\hline $\begin{array}{l}\text { Zamora, } \\
\text { Deán y Cabildo de }\end{array}$ & $\begin{array}{l}\text { Bamba (v) } \\
\text { Congosta, dehesa de } \\
\text { Mazares, dehesa de } \\
\text { San Julián, dehesa de } \\
\text { San Román de los Infantes (v.) } \\
\text { Sánzoles (v) } \\
\text { Valverde, dehesa de }\end{array}$ & $\begin{array}{l}\text { Zamora } \\
\text { Zamora } \\
\text { Zamora } \\
\text { Zamora } \\
\text { Zamora } \\
\text { Zamora } \\
\text { Zamora } \\
\end{array}$ & $\begin{array}{l}32 \text { (28ve, } 1 \mathrm{cl}, 3 \mathrm{vi}) \\
\text { despoblado } \\
\text { despoblado } \\
\text { despoblado } \\
21(17 \mathrm{ve}, 1 \mathrm{cl}, 3 \mathrm{vi}) \\
68 \text { (57 ve, } 2 \mathrm{cl}, 9 \mathrm{vi}) \\
\text { despoblado } \\
\end{array}$ \\
\hline
\end{tabular}

* Datos del censo de 1591.

En cuanto a vasallos dependientes de monasterios consta que hay 460 , distribuidos asi: S. Jerónimo de Benavente; 115; Moreruela: 81; Valparaiso: 51; S. Benito de Zamora: 49; Castañeda: 43; Santa Colomba: 30; Nogales: 78 y La Espina: 13. El núrnero de lugares monásticos es 18. 


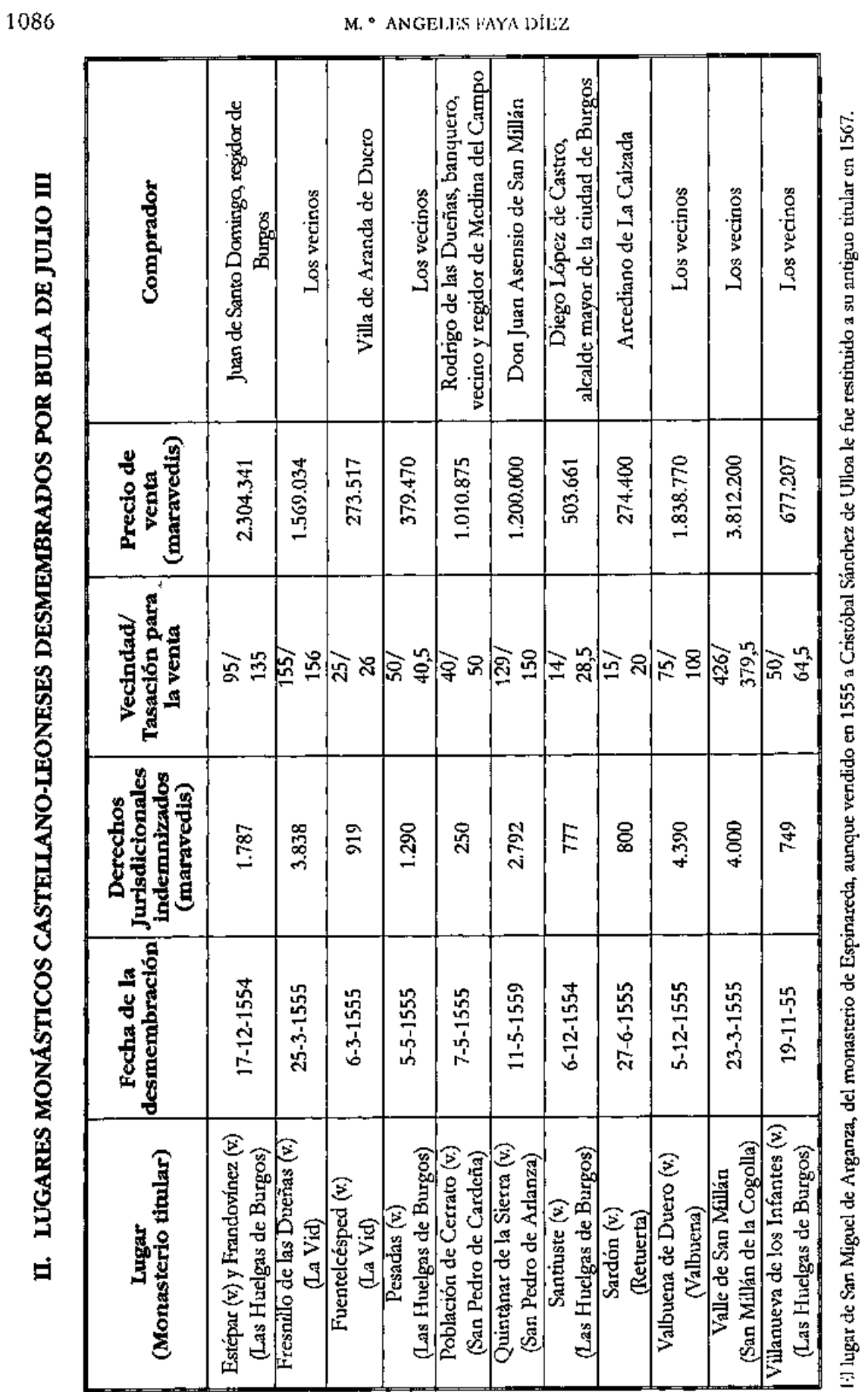

Ihifanid, LVIIl/3, núm 200 (1998) 1045-1096 


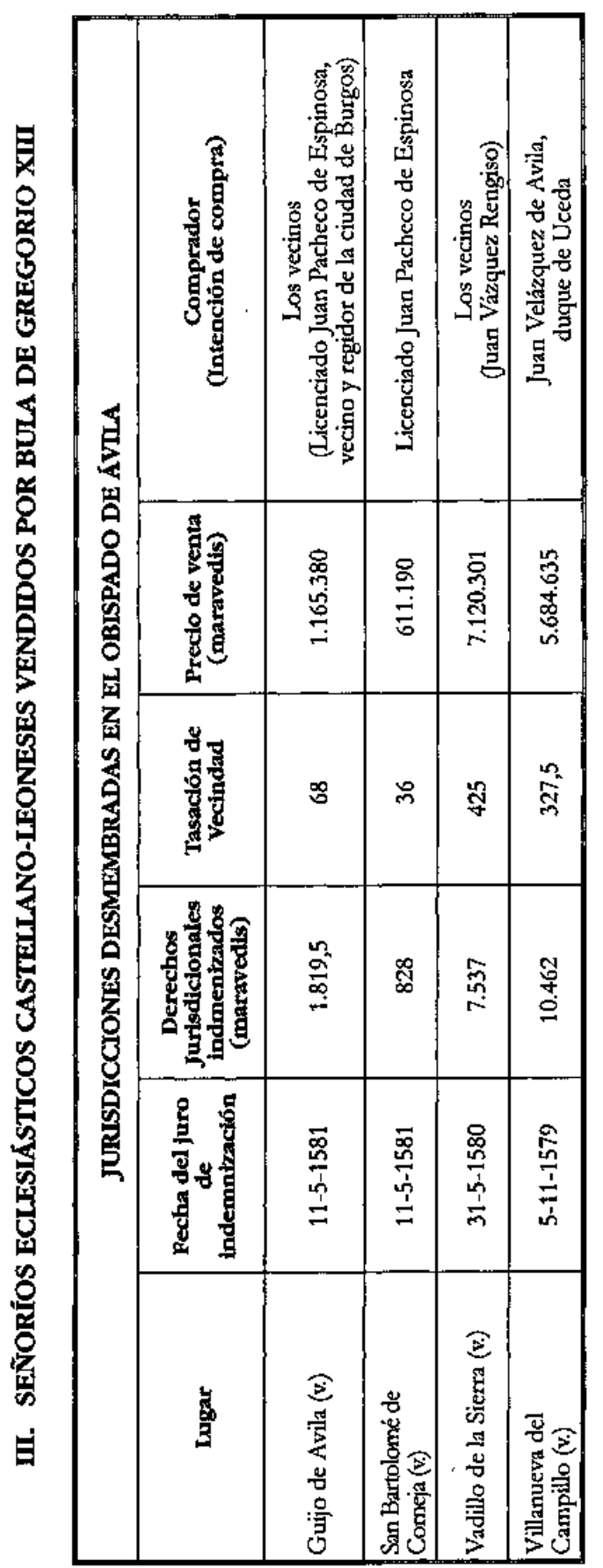

Hispania, LVIII/3, nứm. 200 (1998) 1045-1096 


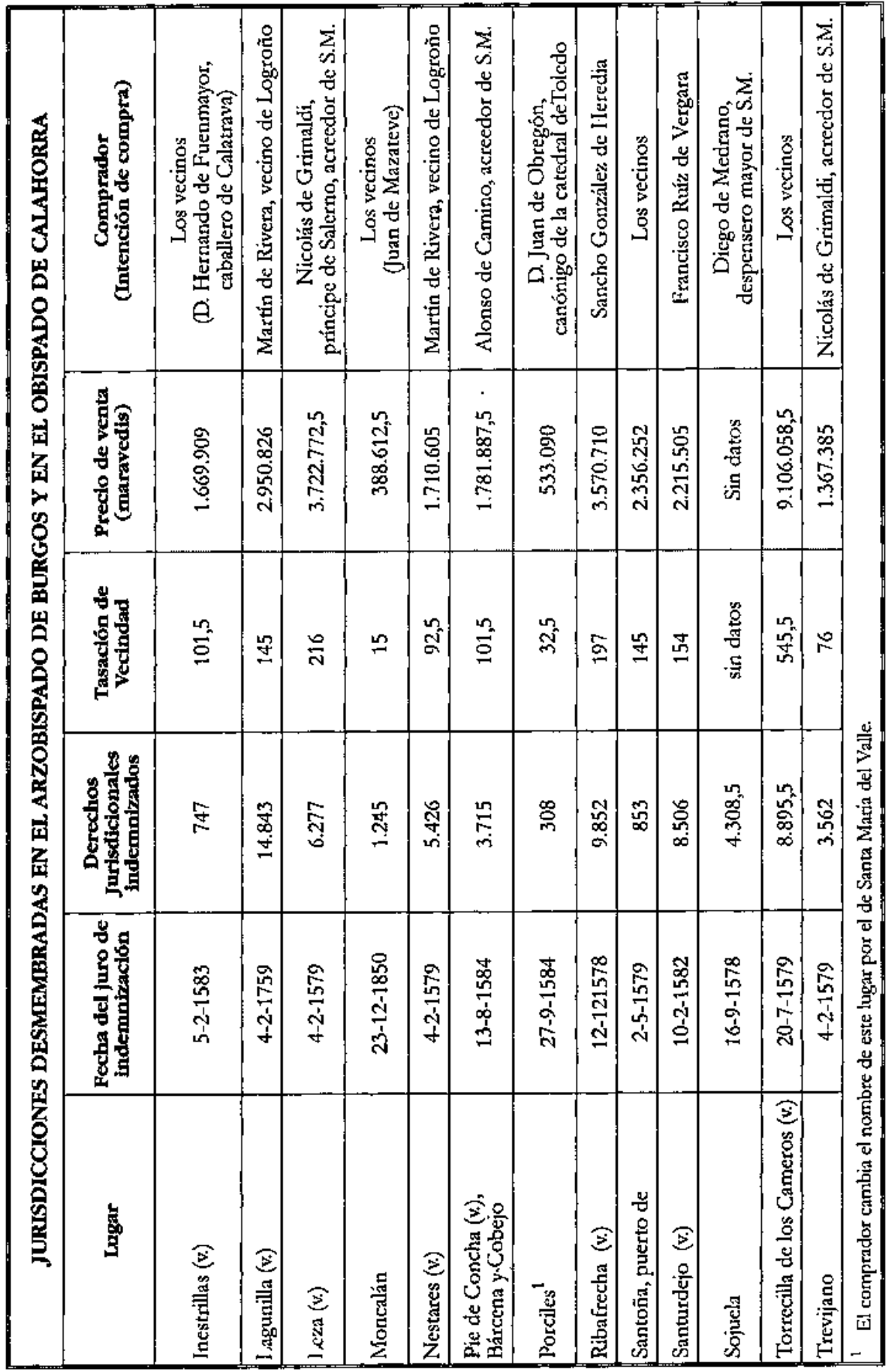

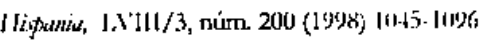




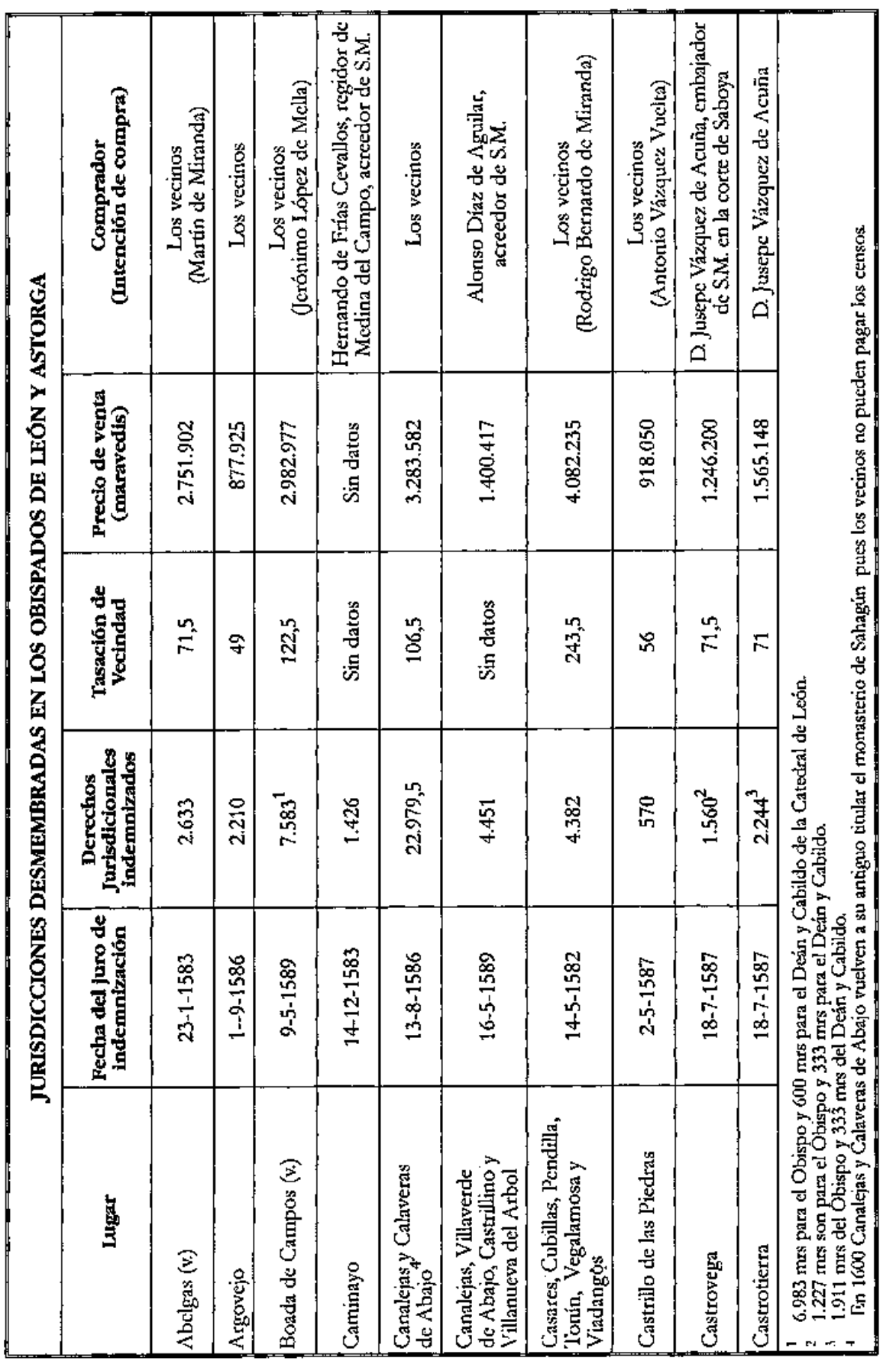

Itipunia, LVIII/3, núm. 200 (1998) t045-t(\%6 


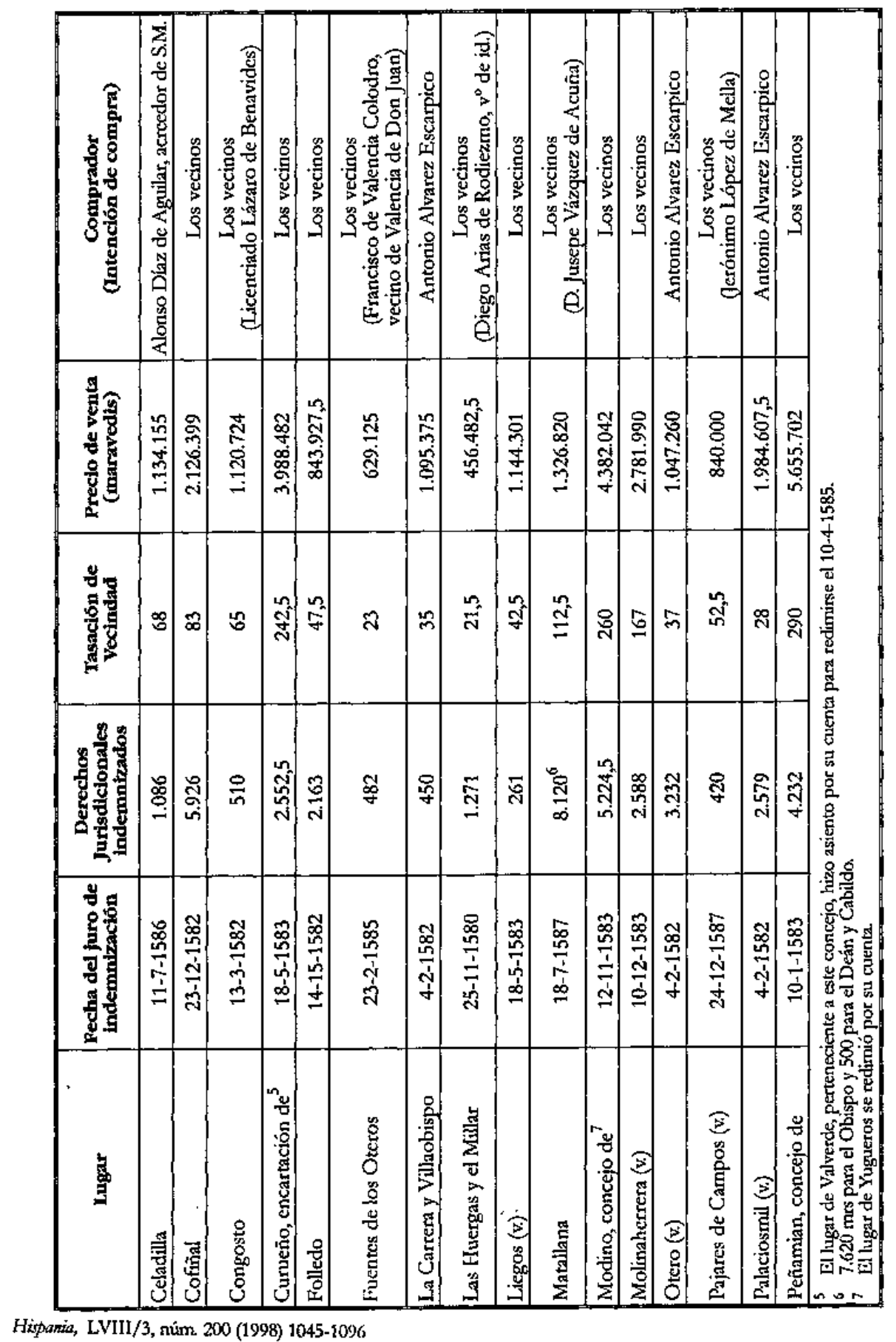




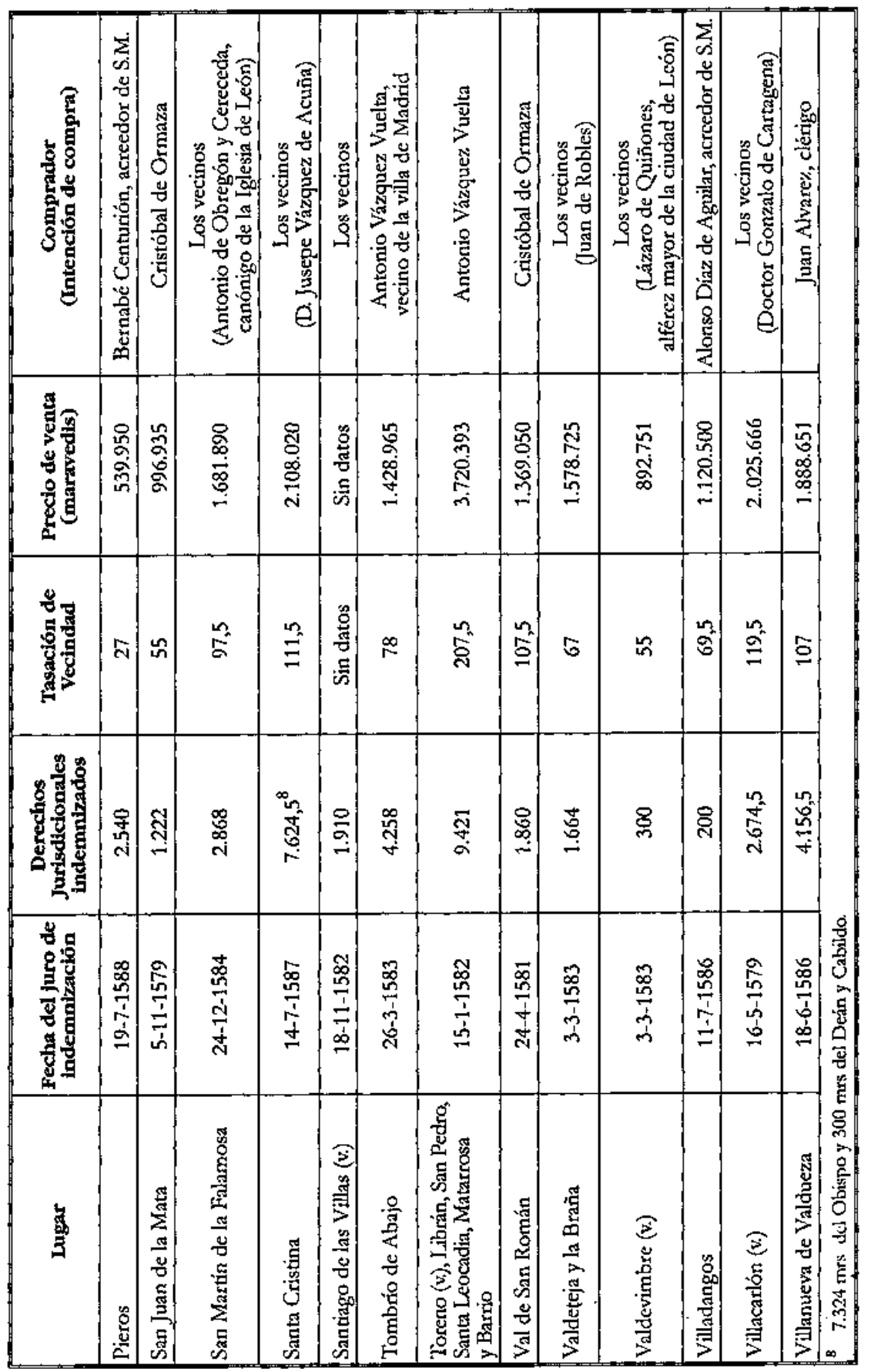

Ilipautia, LVIII/3, núm. 200 (1998) 1045-1096 


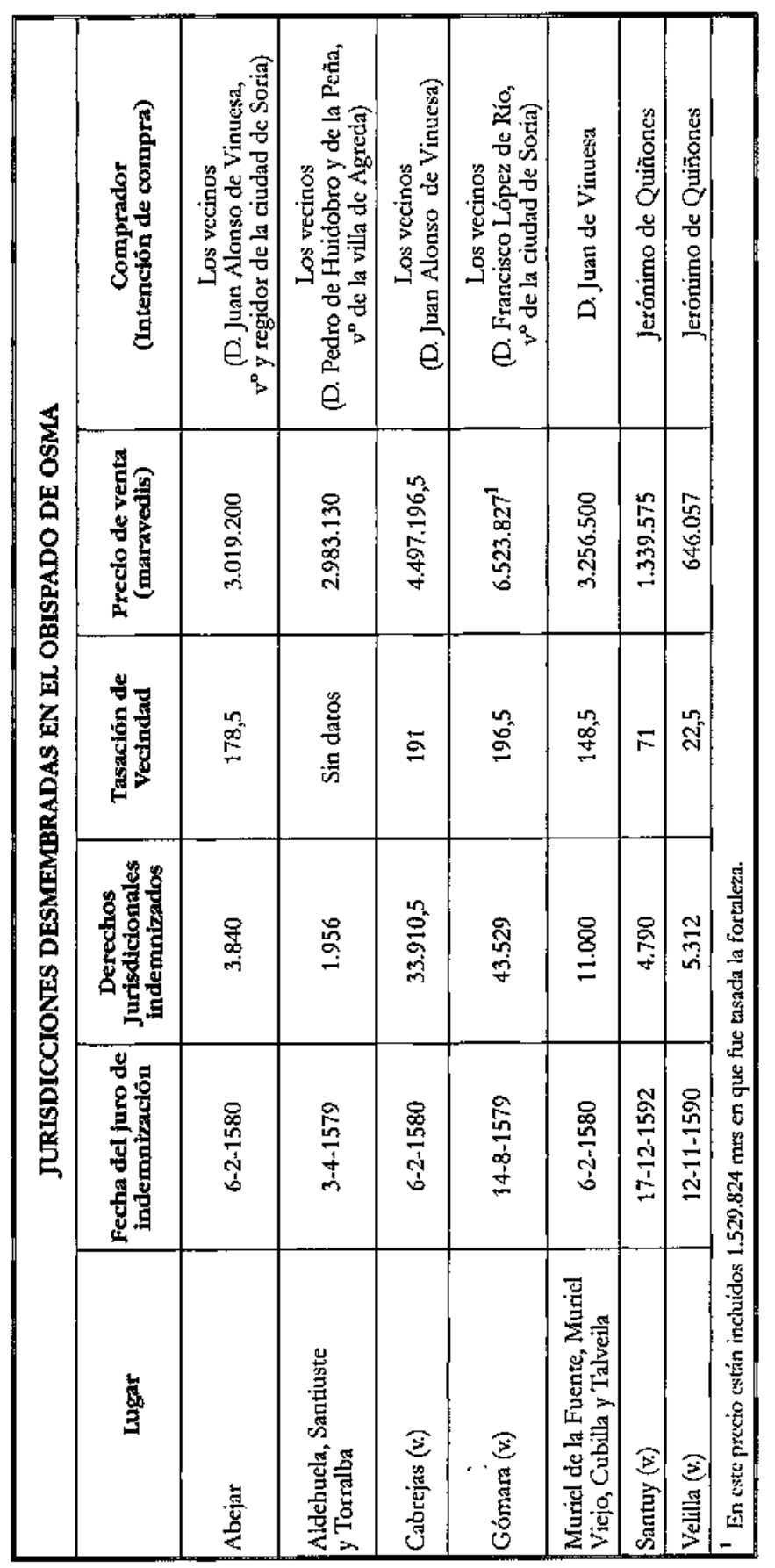

Iitpania, LVIII/3, núm. 200 (1998) 1045-1096 


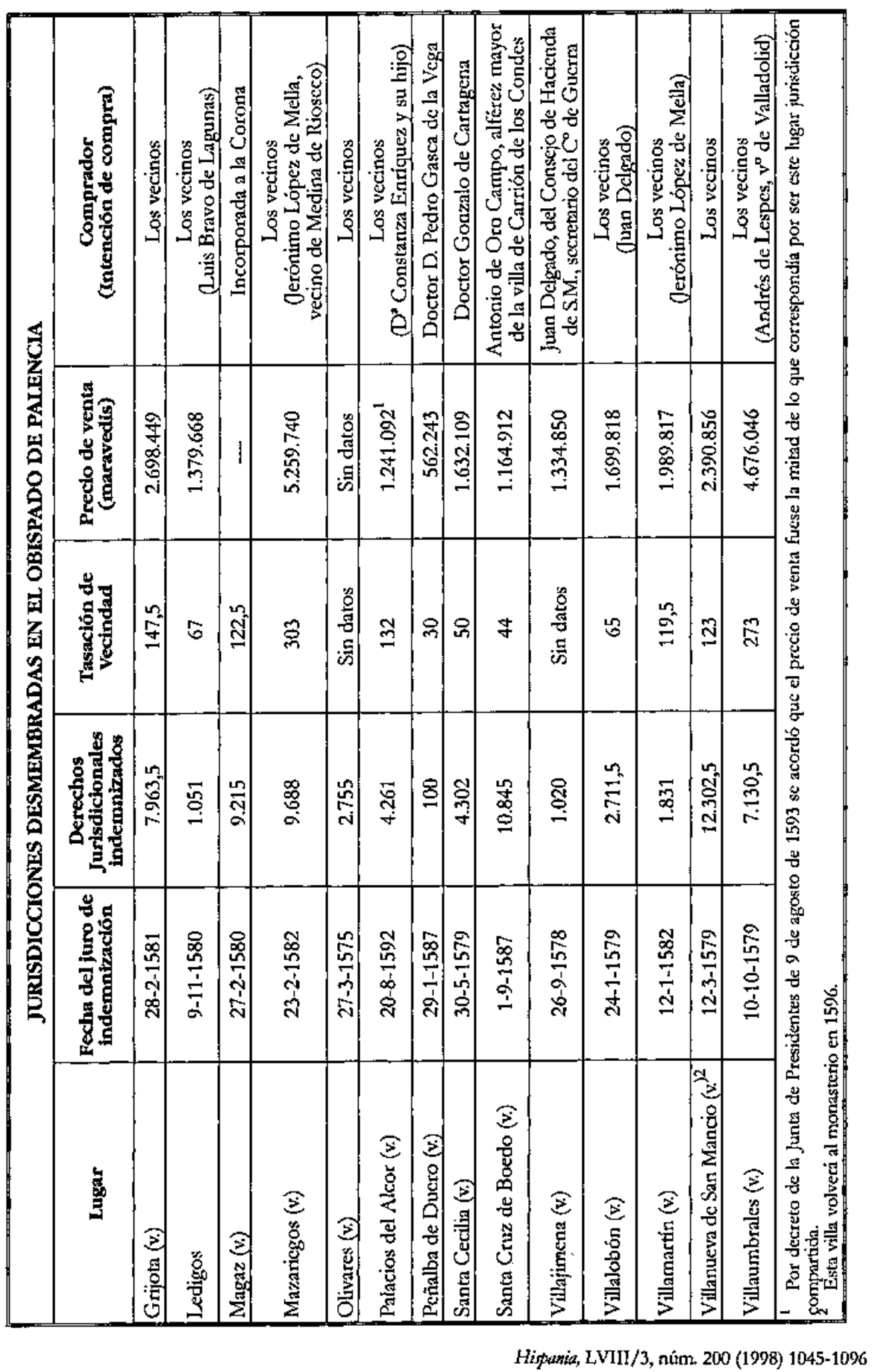




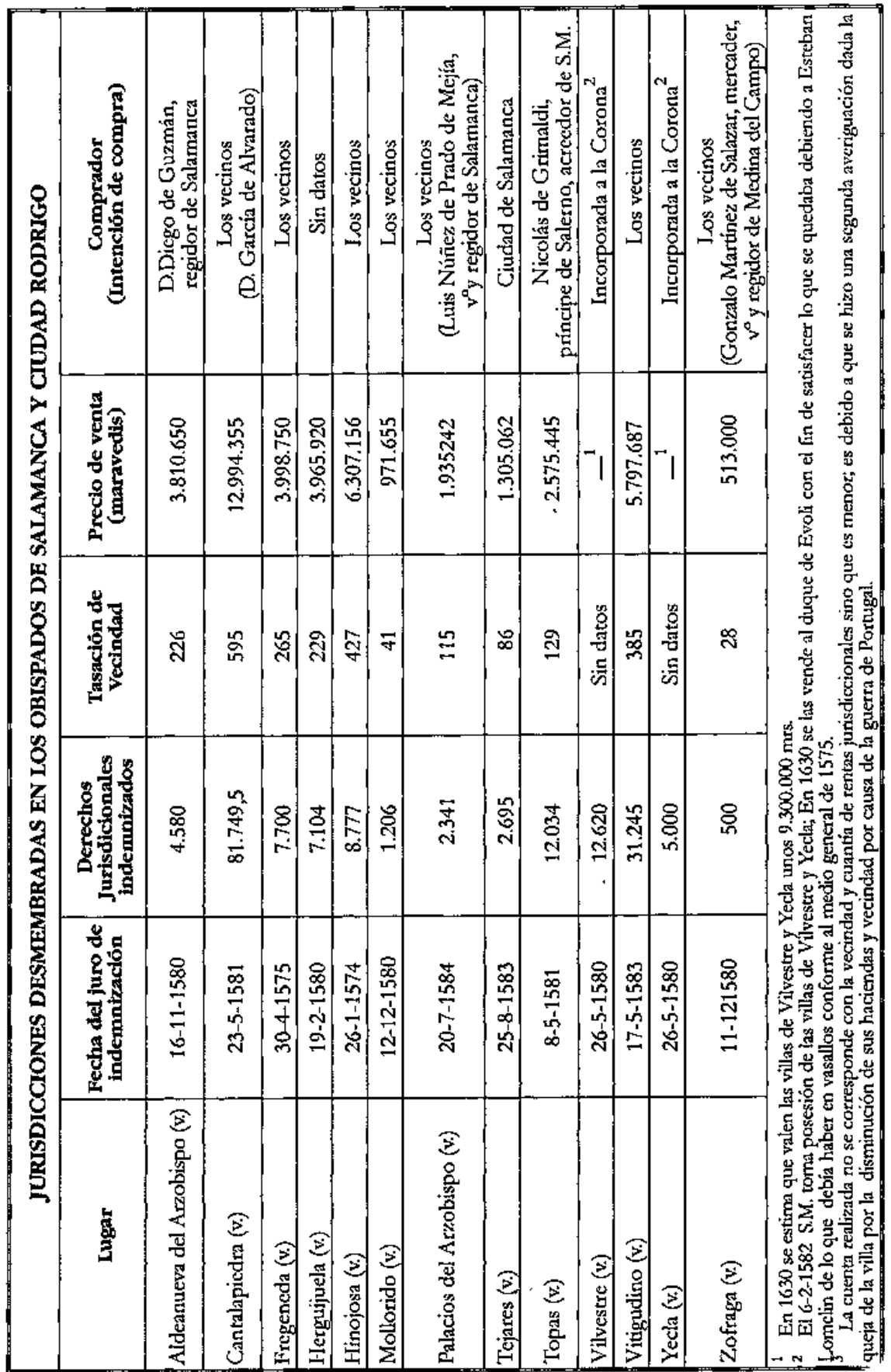

Hipania, LVIII/3, núm. 200 (1998) 1045-1096 


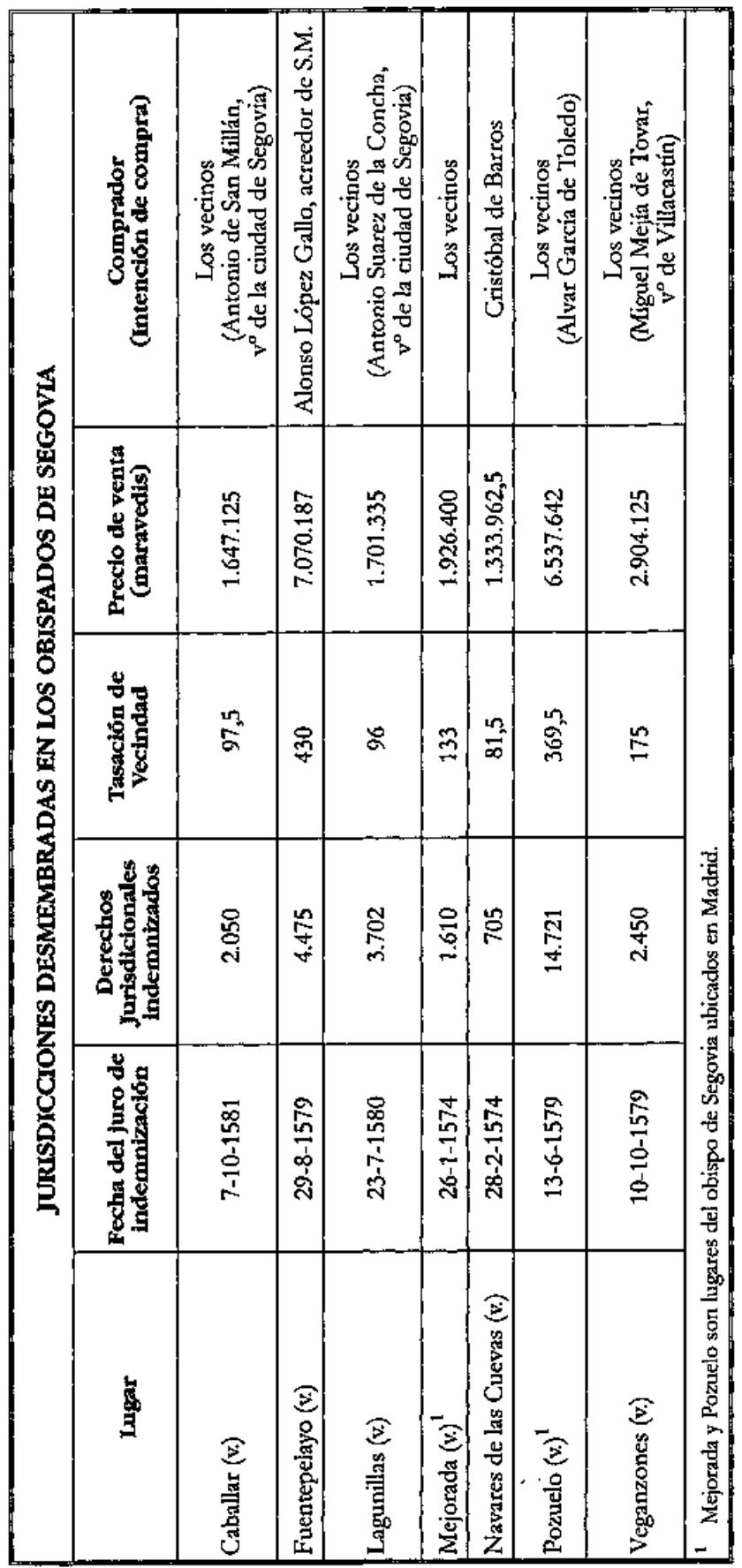

Ihipania, LVIII/3, nưm 200 (1998) 1045- [1'\%), 


\begin{tabular}{|c|c|c|c|c|c|c|c|c|c|c|c|}
\hline \multirow{6}{*}{ 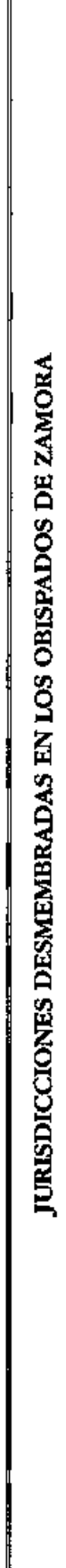 } & 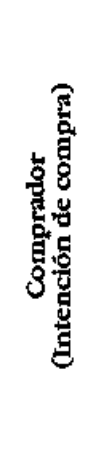 & 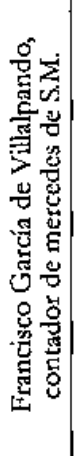 & 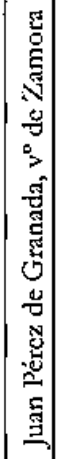 & 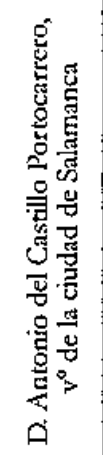 & 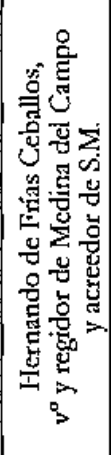 & 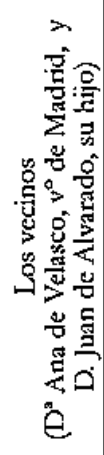 & 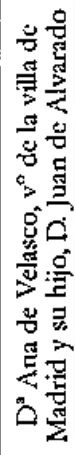 & 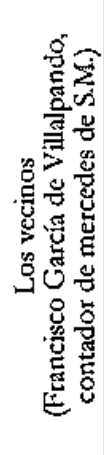 & 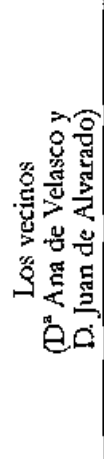 & 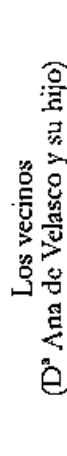 & 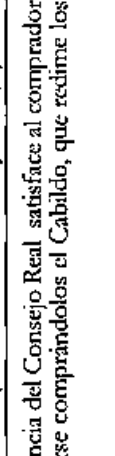 \\
\hline & 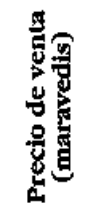 & 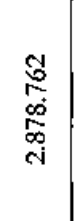 & $\begin{array}{l}8 \\
8 \\
0 \\
0 \\
0\end{array}$ & 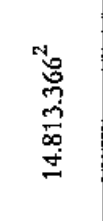 & 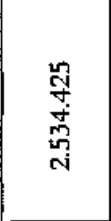 & 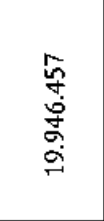 & $\begin{array}{l}\text { h్ } \\
\text { 总 } \\
\text { N }\end{array}$ & 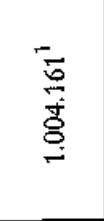 & 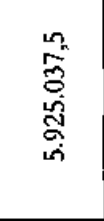 & 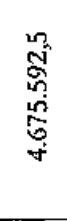 & 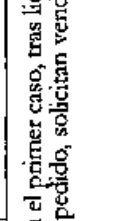 \\
\hline & 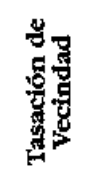 & $\bowtie$ & 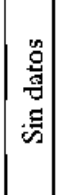 & 尔 & $\stackrel{\infty}{\infty}$ & 嚆 & $\frac{m}{n}$ & $\begin{array}{l}\text { 总 } \\
\text { 哥 } \\
\text { 号 }\end{array}$ & $\frac{n}{\tilde{m}}$ & $\begin{array}{l}\text { an } \\
\text { d. }\end{array}$ & 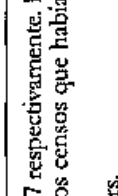 \\
\hline & 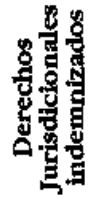 & 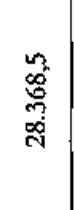 & 용 & 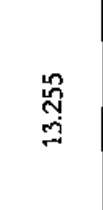 & 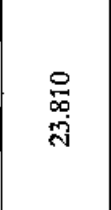 & \begin{tabular}{c} 
今े \\
on \\
\multirow{2}{*}{}
\end{tabular} & 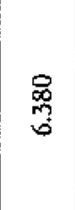 & ఫ్రి & $\begin{array}{l}\text { 亗 } \\
\stackrel{0}{0}\end{array}$ & 莺 & 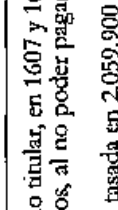 \\
\hline & 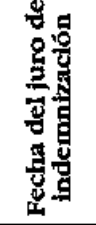 & $\begin{array}{l}\frac{3}{2} \\
\frac{1}{7} \\
\frac{1}{4}\end{array}$ & 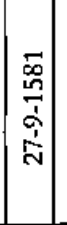 & $\begin{array}{l}\frac{9}{5} \\
\frac{1}{1} \\
\text { in }\end{array}$ & 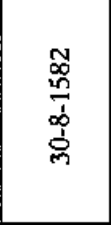 & 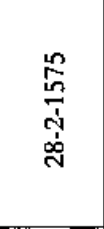 & 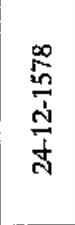 & 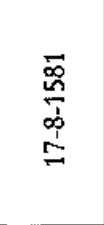 & $\frac{a}{\frac{2}{i}}$ & 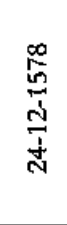 & 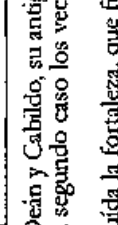 \\
\hline & 总 & 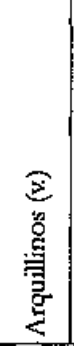 & . & 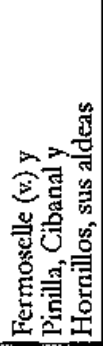 & 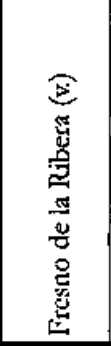 & 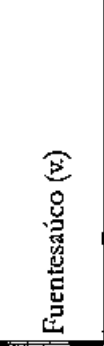 & $\begin{array}{l}\frac{3}{3} \\
\frac{3}{\tilde{y}} \\
\frac{\mathrm{g}}{2}\end{array}$ & 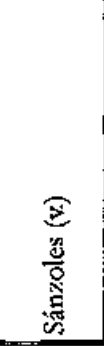 & 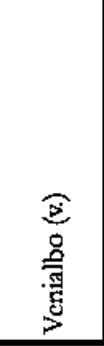 & 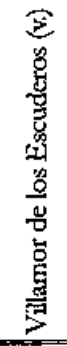 & 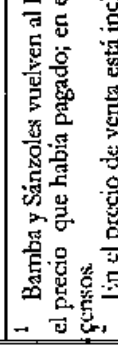 \\
\hline
\end{tabular}

Hitpania, LVIII/3, núm 200 (1998) 1045-10\% 